\title{
Importance of secondary sources in the atmospheric budgets of formic and acetic acids
}

\author{
F. Paulot ${ }^{1}$, D. Wunch ${ }^{1}$, J. D. Crounse ${ }^{2}$, G. C. Toon ${ }^{3}$, D. B. Millet ${ }^{4}$, P. F. DeCarlo ${ }^{5,12,{ }^{*} \text {, C. Vigouroux }}{ }^{6}$, \\ N. M. Deutscher ${ }^{7, * *}$, G. González Abad ${ }^{8}$, J. Notholt ${ }^{9}$, T. Warneke ${ }^{9}$, J. W. Hannigan ${ }^{10}$, C. Warneke ${ }^{11,12}$, \\ J. A. de Gouw ${ }^{11,12}$, E. J. Dunlea ${ }^{12,13}$, M. De Mazière ${ }^{6}$, D. W. T. Griffith ${ }^{7}$, P. Bernath ${ }^{8}$, J. L. Jimenez ${ }^{12,13}$, and \\ P. O. Wennberg ${ }^{1}$ \\ ${ }^{1}$ Division of Engineering and Applied Sciences, California Institute of Technology, Pasadena, California, USA \\ ${ }^{2}$ Division of Chemistry and Chemical Engineering, California Institute of Technology, Pasadena, California, USA \\ ${ }^{3}$ Jet Propulsion Laboratory, California Institute of Technology, Pasadena, California, USA \\ ${ }^{4}$ University of Minnesota, Department of Soil, Water and Climate, St. Paul, Minnesota, USA \\ ${ }^{5}$ Department of Atmospheric and Oceanic Sciences, University of Colorado, Boulder, Colorado, USA \\ ${ }^{6}$ Belgian Institute for Space Aeronomy, Brussels, Belgium \\ ${ }^{7}$ School of Chemistry, University of Wollongong, Wollongong, Australia \\ ${ }^{8}$ Department of Chemistry, University of York, York, UK \\ ${ }^{9}$ Institute of Environmental Physics, Bremen, Germany \\ ${ }^{10}$ National Center for Atmospheric Research, Boulder, Colorado, USA \\ ${ }^{11}$ Earth System Research Laboratory, Chemical Sciences Division, NOAA, Boulder, Colorado, USA \\ ${ }^{12}$ Cooperative Institute for Research in Environmental Sciences, University of Colorado, Boulder, Colorado, USA \\ ${ }^{13}$ Department of Chemistry and Biochemistry, University of Colorado, Boulder, Colorado, USA \\ *now at: AAAS Science and Technology Policy Fellow hosted at the US EPA, Washington, DC, USA \\ ** now at: Institute of Environmental Physics, Bremen, Germany
}

Received: 18 September 2010 - Published in Atmos. Chem. Phys. Discuss.: 20 October 2010

Revised: 23 February 2011 - Accepted: 25 February 2011 - Published: 4 March 2011

\begin{abstract}
We present a detailed budget of formic and acetic acids, two of the most abundant trace gases in the atmosphere. Our bottom-up estimate of the global source of formic and acetic acids are $\sim 1200$ and $\sim 1400 \mathrm{Gmol} \mathrm{yr}^{-1}$, dominated by photochemical oxidation of biogenic volatile organic compounds, in particular isoprene. Their sinks are dominated by wet and dry deposition. We use the GEOS-Chem chemical transport model to evaluate this budget against an extensive suite of measurements from ground, ship and satellite-based Fourier transform spectrometers, as well as from several aircraft campaigns over North America. The model captures the seasonality of formic and acetic acids well but generally underestimates their concentration, particularly in the Northern midlatitudes. We infer that the source of both carboxylic acids may be up to $50 \%$ greater than our estimate and report evidence for a long-lived missing secondary source of carboxylic acids that may be associated with the aging of organic aerosols. Vertical profiles
\end{abstract}

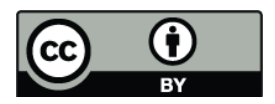

Correspondence to: F. Paulot

(paulot@caltech.edu) of formic acid in the upper troposphere support a negative temperature dependence of the reaction between formic acid and the hydroxyl radical as suggested by several theoretical studies.

\section{Introduction}

Formic $(\mathrm{HCOOH}$, hereafter $\mathrm{FA})$ and acetic $\left(\mathrm{CH}_{3} \mathrm{COOH}\right.$, hereafter AA) acids are among the most abundant and ubiquitous trace gases in the atmosphere. They have been detected in remote, rural, polar, marine and urban environments in the gas-phase as well as in clouds and in aerosols (Keene and Galloway, 1988; Chebbi and Carlier, 1996; Khare et al., 1999).

Sources of FA and AA include direct emissions from biomass burning, biofuel, fossil fuel, soil, vegetation, as well as secondary production from gas-phase and aqueous photochemistry (Chebbi and Carlier, 1996; Khare et al., 1999). Measurements of the isotopic composition of FA and AA have shown that they are primarily composed of modern carbon (Glasius et al., 2000, 2001), consistent with major

Published by Copernicus Publications on behalf of the European Geosciences Union. 
biogenic and biomass burning sources. Furthermore, most field measurements show a remarkable correlation between FA and AA suggesting similar sources. The sources of FA and AA remain, however, very poorly understood and several investigations (Poisson et al., 2000; von Kuhlmann et al., 2003a; Ito et al., 2007) have pointed to large inconsistencies between measurements and model predictions.

Sinks of FA and AA are better understood. Both acids are relatively long-lived in the gas-phase with respect to $\mathrm{OH}$ photooxidation $\left(\tau_{\mathrm{FA}} \simeq 25\right.$ days and $\tau_{\mathrm{AA}} \simeq 10$ days at $T=260 \mathrm{~K}$ and $[\mathrm{OH}]=10^{6}$ molec $\mathrm{cm}^{-3}$ ). Because both gases are very soluble, their primary atmospheric sink is thought to be deposition (Chebbi and Carlier, 1996). Irreversible uptake on dust can also be an important regional sink (Falkovich et al., 2004).

Better constraints on the budget of FA and AA are important to understand patterns of rain acidity particularly in remote regions (Galloway et al., 1982). More generally, since FA and AA are major trace gases in the atmosphere and have few anthropogenic sources, the study of their budget offers a glimpse at the interaction between the biosphere and the atmosphere.

In this work, we derive a detailed inventory of FA and AA sources and sinks. We then use a chemical transport model to evaluate the resulting budget against measurements from an extensive suite of ground, aircraft and satellite-based measurements. Major discrepancies between the model and the measurements are investigated and several avenues for further research are discussed.

\section{Global budget}

We use the GEOS-Chem global 3-D chemical transport model (Bey et al., 2001) to investigate the budget of FA and AA. In the standard GEOS-Chem mechanism (v8.3), photochemical sources of AA include ozonolysis of isoprene and reaction of peroxyacyl radicals with $\mathrm{HO}_{2}$ and other peroxy radicals $\left(\mathrm{RO}_{2}\right)$ while sinks are limited to its reaction with $\mathrm{OH}$. FA is not treated explicitly.

In the following, we describe the sources and sinks of FA and AA and their implementation into the GEOS-Chem framework. In this work, the model is driven by the GEOS-5 assimilated meteorology from the NASA Goddard Earth Observing System. The horizontal resolution is degraded here to $4^{\circ} \times 5^{\circ}$ and the vertical resolution to 47 vertical layers. The model is run from 2004 to 2008 following a one-year spin-up.

\subsection{Emissions}

\subsubsection{Terrestrial vegetation}

Terrestrial vegetation emits both FA and AA (e.g. Kesselmeier, 2001). Emissions by trees are triggered by light and are well correlated with the transpiration rate. In contrast, crops have been reported not to emit detectable amounts of FA or AA (Kesselmeier et al., 1998). FA emissions by plants are related to the $\mathrm{C}_{1}$ pathway, ethene synthesis and photo-respiration (Kesselmeier and Staudt, 1999). The emission of AA by plants occurs as the result of the hydrolysis of acetyl-coA, a product of the degradation of fats and carbohydrates (Kesselmeier and Staudt, 1999).

We use the Model of Emissions of Gases and Aerosols from Nature (MEGAN) v2.1 (Guenther et al., 2006) implemented in GEOS-Chem as described by Millet et al. (2010) to compute biogenic emissions from each GEOS-Chem grid cell $(E)$ :

$$
E=\gamma \sum_{i} \varepsilon_{i} \chi_{i}
$$

where the sum is over the number of plant functional types with baseline emission factor, $\varepsilon$, and fractional coverage, $\chi$. For both FA and AA, $\varepsilon$ are $30 \mu \mathrm{g}\left(\mathrm{m}^{-2} \mathrm{~h}^{-1}\right)$ for trees and

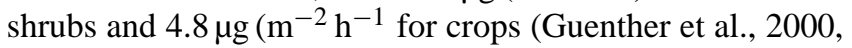
updated on the basis of recent measurements (A. Guenther, personal communication, 2010)). The emission activity factor, $\gamma$, accounts for the variability in the local environment (e.g., temperature, light, leaf area, soil moisture). In particular for FA and AA:

$\gamma=\exp (\beta(T-303)) \gamma_{\text {(other) }}$ with $\beta=0.08$ and $T$ inK

where $\gamma_{(\text {other) }}$ is described in Millet et al. (2010) and $T$ is the current leaf temperature.

\subsubsection{Biomass burning and biofuel}

Both FA and AA have been measured in biomass burning plumes (Goode et al., 2000; Christian et al., 2003; Yokelson et al., 2009). We estimate biomass burning emissions of FA and AA from biomass burning emissions inventory (GFEDv2 Randerson et al., 2006) using the emission factors (EF) summarized in Table 1. Emissions from biofuels are calculated in the same way using the $\mathrm{CO}$ emission inventory from Yevich and Logan (2003).

We note that the emission factors used in this study are generally smaller than the ones reported by Andreae and Merlet (2001) for FA but larger for AA. These changes reflect the very large variability in the reported emission factors.

\subsubsection{Fossil fuel}

Emissions of FA and AA from motor vehicles were first measured by Kawamura et al. (1985). Here we estimate fossil fuel FA and AA from CO fossil fuel emissions (Duncan et al., 2007) scaled by the emission ratios derived by Talbot et al. (1988) at the Hampton Roads Bridge Tunnel (Virginia): $2.1 \times 10^{-4}$ FA per $\mathrm{CO}$ and $4.2 \times 10^{-4}$ AA per CO. 
Table 1. Biomass burning emission factors for FA and AA (in $g$ per kg of dry matter, Yokelson personal communication and Akagi et al. (2010)). Emission factors from Andreae and Merlet (2001) are indicated in parentheses.

\begin{tabular}{ccccc}
\hline & Savanna & Tropical & Boreal & Biofuel $^{*}$ \\
\hline FA & $0.18(0.7)$ & $0.42(1.1)$ & $0.80(2.9 \pm 2.4)$ & $0.22(0.13)$ \\
AA & $1.58(1.3)$ & $3.11(2.1)$ & $4.05(3.8 \pm 1.8)$ & $4.97(0.4-1.4)$ \\
\hline
\end{tabular}

* Derived from open-cooking.

\subsubsection{Agricultural emissions}

Large emissions of acetic acid are associated with intensive animal farming (from both cattle and cattle waste Shaw et al., 2007). Ngwabie et al. (2008) used the correlation between AA and ammonia to derive emission factors $\left(2 \times 10^{-3}-0.2 \mathrm{gC} / \mathrm{gNH}_{3}\right.$ and a global estimate of AA emissions from cattle (4-17 $\left.\mathrm{Gmol} \mathrm{yr}^{-1}\right)$. Using an emission factor of $0.1 \mathrm{gC} / \mathrm{gNH}_{3}$ and the anthropogenic emissions of ammonia (Bouwman and Hoek, 1997) located on agricultural lands, we estimate the global soil emissions of AA to be $\sim 40 \mathrm{Gmol} \mathrm{yr}^{-1}$.

Ethanol, which has nearly the same molecular weight as FA, is a major emission of cattle farming. This makes it difficult to quantify the emissions of FA by proton transfer mass spectrometry (PTRMS), the most common technique for these investigations. We assume that the emissions of FA (in moles) are equal to the emissions of AA. This corresponds to $40 \%$ of the upper estimate of ethanol global emissions by Ngwabie et al. (2008).

Both FA and, to a lesser extent, AA farming emission estimates are larger than those from Ngwabie et al. (2008) and probably represent upper estimates. However, the contribution of agricultural activities to the FA and AA budget is likely to be underestimated as one can expect FA and AA production from the photooxidation of volatile compounds emitted as a result of farming activities but not represented in the model.

\subsubsection{Soil}

FA and AA production by soil bacteria is well documented with soil concentrations ranging from 2 to $5 \mathrm{~mol} \mathrm{~m}^{-3}$ (Sposito, 1989, p. 66). The few studies of FA and AA emissions (Sanhueza and Andreae, 1991; Enders et al., 1992) suggest that soil emission is an important source of acids where production from terrestrial vegetation is low.

Sanhueza and Andreae (1991) reported emissions of FA (AA) of $\sim 0.4 \mathrm{nmol}\left(\mathrm{m}^{-2} \mathrm{~s}^{-1}\right)\left(0.2 \mathrm{nmol}\left(\mathrm{m}^{-2} \mathrm{~s}^{-1}\right)\right)$ at noon over dry savanna soil. Emissions of both acids were found to be temperature dependent. Here we approximate the temperature dependence reported by Sanhueza and Andreae (1991) using an exponential law:

$$
\begin{aligned}
& E_{\mathrm{FA}}^{\mathrm{dry}}(\text { savanna })=1.7 \times 10^{-3} \times(\exp (0.119 \times T)-1), \\
& T>0{ }^{\circ} \mathrm{C}\left(R^{2}=0.66\right) \\
& E_{\mathrm{AA}}^{\mathrm{dry}}(\text { savanna })=2.5 \times 10^{-3} \times(\exp (0.091 \times T)-1), \\
& T>0{ }^{\circ} \mathrm{C}\left(R^{2}=0.50\right)
\end{aligned}
$$

where $T$ is the soil temperature in ${ }^{\circ} \mathrm{C}$ and $E_{X}$ is the emission of the acid in $\mathrm{nmol}\left(\mathrm{m}^{-2} \mathrm{~s}^{-1}\right)$. This corresponds to an average emission of $\overline{E_{\mathrm{FA}}}=1.8 \times 10^{-1} \mathrm{nmol}\left(\mathrm{m}^{-2} \mathrm{~s}^{-1}\right)$ and $\overline{E_{\mathrm{AA}}}=8.4 \times 10^{-2} \mathrm{nmol}\left(\mathrm{m}^{-2} \mathrm{~s}^{-1}\right)$ over the $30^{\circ} \mathrm{C}$ to $40^{\circ} \mathrm{C}$ temperature range.

For a similar environment and using a much larger dataset, Yienger and Levy (1995) derived $\overline{E_{\mathrm{NO}}}=1.89 \times$ $10^{-1} \mathrm{nmol}\left(\mathrm{m}^{-2} \mathrm{~s}^{-1}\right)$. We use the soil emissions of NO from Yienger and Levy (1995) in other environments to infer the emissions of FA and AA (Table 2). This assumes that the ratio between the emissions of FA (AA) and NO is independent of the environment type and that the emissions of FA and AA exhibit the same temperature dependence as the one measured by Sanhueza and Andreae (1991). Field measurements are clearly needed to assess these assumptions.

Because of the weak acidity of FA $(\mathrm{pKa}=3.75)$ and AA (4.75), their soil emissions are likely to depend on soil $\mathrm{pH}$ under wet conditions. We assume that the emissions listed in Table 2 are at $\mathrm{pH}=\mathrm{pKa}(\mathrm{FA} / \mathrm{AA})$ and $30^{\circ} \mathrm{C}$, i.e. that they correspond to half of the maximum emissions under wet conditions. Under these assumptions, the wet emissions are thus obtained by scaling the baseline wet emission by the following factor:

$\exp \left(-\frac{\Delta H_{X}}{R}\left(\frac{1}{T_{\text {soil }}}-\frac{1}{303.15}\right)\right) \times \frac{2}{1+10^{\mathrm{PH}-\mathrm{pKax}}}$

with $X=\{\mathrm{FA}, \mathrm{AA}\}$

where the soil $\mathrm{pH}$ is taken from the ISRIC World Soil Information Database (http://www.isric.org) and $\Delta H$ is the heat of dissolution at $298 \mathrm{~K}$.

Sanhueza and Andreae (1991) also reported an increase in AA emissions after watering the soil, while FA emissions were suppressed. The AA emission increase hints at the existence of water-stressed AA-producing microorganisms, similar to denitrifying bacteria (Davidson, 1992). Here, we use the same pulsing factors for AA as the one derived by Yienger and Levy (1995) for the soil emissions of NO. AA pulsing increases AA soil emissions by $\sim 10 \%$ globally.

\subsection{Photochemical sources of formic and acetic acids}

\subsubsection{Terrestrial biogenic precursors}

The oxidation of biogenic compounds, and in particular their ozonolysis has been suggested to be a major source of FA and AA (Jacob and Wofsy, 1988; Neeb et al., 1997). 
Table 2. Soil emissions of formic and acetic acids at $T_{\text {soil }}=30^{\circ} \mathrm{C}$ in $\mathrm{nmol}\left(\mathrm{m}^{-2} \mathrm{~s}^{-1}\right)$ for different land types.

\begin{tabular}{lcccc}
\hline Land Type $^{*}$ & \multicolumn{2}{c}{ Formic Acid } & \multicolumn{2}{c}{ Acetic Acid } \\
& wet & dry & wet & dry \\
\hline Agriculture (not Rice) & $1.8 \times 10^{-1}$ & - & $1.1 \times 10^{-1}$ & - \\
Agriculture (Rice) & $5.9 \times 10^{-3}$ & - & $3.5 \times 10^{-3}$ & - \\
Conifer and other deciduous & $1.47 \times 10^{-2}$ & $4.9 \times 10^{-3}$ & $8.8 \times 10^{-3}$ & $2.9 \times 10^{-3}$ \\
Desert & 0 & 0 & 0 & 0 \\
Drought deciduous & $2.9 \times 10^{-2}$ & $8.9 \times 10^{-3}$ & $1.8 \times 10^{-2}$ & $5.4 \times 10^{-3}$ \\
Grassland & $1.8 \times 10^{-1}$ & $5.9 \times 10^{-2}$ & $1.1 \times 10^{-1}$ & $3.6 \times 10^{-2}$ \\
Tropical rain forest & 1.3 & $1.9 \times 10^{-1}$ & $7.7 \times 10^{-1}$ & $1.2 \times 10^{-1}$ \\
Tundra & $2.4 \times 10^{-2}$ & $8.2 \times 10^{-3}$ & $1.5 \times 10^{-2}$ & $5.0 \times 10^{-3}$ \\
Woodland & $8.3 \times 10^{-2}$ & $3.2 \times 10^{-2}$ & $5.0 \times 10^{-2}$ & $1.9 \times 10^{-2}$ \\
Wetland & $1.5 \times 10^{-3}$ & - & $8.8 \times 10^{-4}$ & - \\
\hline
\end{tabular}

* Wang et al. (1998); Wang and Jacob (1998).

Here we update the photochemical oxidation mechanism of isoprene, a non methane hydrocarbon which accounts for $\sim 30-50 \%$ of biogenic emissions (Guenther et al., 2006), to include sources of FA from products of its photooxidation with $\mathrm{OH}$ : hydroxyacetone, glycolaldehyde and isoprene nitrates (Butkovskaya et al., 2006a,b; Paulot et al., 2009, cf. Supplement). Ozonolysis of methylvinylketone (MVK) and methacrolein (MACR), two major products of isoprene photooxidation, are also known to yield FA (Aschmann et al., 1996; Grosjean et al., 1993). In contrast, isoprene photochemistry has long been thought to be an insignificant source of AA (Jacob and Wofsy, 1988). Recent experimental evidence suggests, however, that the photooxidation of hydroxyacetone produces significant amounts of AA (Butkovskaya et al., 2006b) at low temperature. Isoprene is also a significant source of peroxy acetyl radical (PA), which reacts with $\mathrm{HO}_{2}$ to yield AA with a yield of $15 \%$ (Hasson et al., 2004; Dillon and Crowley, 2008).

The OH-oxidation of methylbutenol (MBO), a volatile organic compound emitted in large quantities by coniferous trees (Harley et al., 1998), also yields glycolaldehyde and hydroxymethylpropanal (HMPR), a precursor of acetone (Carrasco et al., 2006), and thus of AA via PA. MBO ozonolysis has also been shown to yield FA as well as acetone and HMPR (Carrasco et al., 2007).

The $\mathrm{OH}$-oxidation of various monoterpenes has been reported to produce FA. However, the yield remains very uncertain. For instance, reported FA yields from the $\mathrm{OH}$ oxidation of $\alpha$-pinene range from 7\% (Orlando et al., 2000) to $28 \%$ (Larsen et al., 2001). Yields greater than $50 \%$ have been reported for limonene (Larsen et al., 2001). Ozonolysis of various monoterpenes also yields FA and AA (Lee et al., 2006). Monoterpenes are lumped into one species, MONX, in the GEOS-Chem chemical mechanism. We adopt a FA yield of $15.5 \%$ for the reaction of MONX with OH and a FA (AA) yield of $7.5 \%(8 \%)$ for its ozonolysis. The formation of carboxylic acids in the oxidation of MONX by $\mathrm{OH}$ has been ascribed to the reaction of stabilized $\alpha$-hydroxyalkyl radicals with NO (Orlando et al., 2000; Larsen et al., 2001). However, Peeters et al. (2001) calculated that this reaction is only competitive with their thermal decomposition to aldehyde $+\mathrm{HO}_{2}$ under laboratory conditions (NO $\sim 1-10 \mathrm{ppmv}$ ), suggesting that the yield of FA from the first steps of MONX photooxidation is negligible (Peeters et al., 2001; Capouet et al., 2004). Conversely, the very simplified representation of MONX secondary photochemistry in GEOS-Chem may result in an underestimate of their overall FA/AA forming potential.

The $\mathrm{OH}$-oxidation of acetaldehyde, whose sources include large emissions from the terrestrial and marine biosphere (Millet et al., 2010), is an important source of AA via $\mathrm{PA}+\mathrm{HO}_{2}$. The modification to the GEOS-Chem mechanism are summarized in Table S4.

\subsubsection{Marine precursors}

Ozonolysis of marine biogenic emissions has been suggested to provide a source of FA and AA in the marine atmosphere (Arlander et al., 1990; Sanhueza et al., 1996; Baboukas et al., 2000).

In this study, we include monthly marine emissions of isoprene, acetaldehyde, ethene and larger alkenes. Acetaldehyde marine emissions $\left(\sim 1.3 \mathrm{Tmol} \mathrm{yr}^{-1}\right)$ are from Millet et al. (2010) and isoprene sources are from Arnold et al. (2009) (top-down estimate : $28 \mathrm{Gmol} \mathrm{yr}^{-1}$ ). Emissions of ethene $\left(162 \mathrm{Gmol} \mathrm{yr}^{-1}\right)$ and larger alkenes $\left(164 \mathrm{Gmol} \mathrm{yr}^{-1}\right)$ are inferred from isoprene emissions using the flux ratios observed by Broadgate et al. (1997). 


\subsubsection{Anthropogenic/biomass burning precursors}

In addition to fresh emissions from biomass burning or anthropogenic sources, production of FA and AA within fire plumes has been measured in many (Goode et al., 2000; Gao et al., 2003; Yokelson et al., 2003; Herndon et al., 2007) but not all instances (de Gouw et al., 2006). Here, we include formation of FA and AA from the photooxidation of acetylene (Hatakeyama et al., 1986), ethene and propene (and higher alkenes).

Anthropogenic inventories for $\mathrm{CO}$ are described by Bey et al. (2001) and biofuel emissions by Yevich and Logan (2003). Recent updates of these inventories are described by Millet et al. (2010). Emissions and photooxidation of acetylene, propene and ethene, which are precursors of FA and AA, were recently included or updated by Fu et al. (2008) in the GEOS-Chem model. In addition we include biomass burning emission of hydroxyacetone and glycolaldehyde (Fu et al., 2008), two precursors of FA and AA.

\subsection{Sources not treated}

Graedel and Eisner (1988) estimate that emissions of FA from formicine ants could exceed motor vehicle and biomass burning emissions. The overall contribution of formicine ants to the FA budget is, however, likely to be limited (Chebbi and Carlier, 1996) but may be important in ecosystems where formicine ants are abundant (e.g., tropical forests).

Aqueous phase oxidation of formaldehyde within clouds has been proposed to be a non-negligible source of FA in remote environments (Chameides, 1984; Jacob, 1986). However Lelieveld and Crutzen (1991) argued that the very fast aqueous oxidation of FA would greatly diminish the role of cloud chemistry as a source of FA.

The source of FA and AA from enol photochemistry is not included in the model (Archibald et al., 2007). Enol are known intermediates in combustion (Taatjes et al., 2005) and could originate from keto-enol tautomerizations catalyzed by carboxylic acids (da Silva, 2010). However, the importance of these processes as a source of FA and AA is poorly known and additional experimental constraints are needed to include these processes in a global model.

\subsection{Sinks}

\subsubsection{Photochemical}

FA reacts with $\mathrm{OH}$ primarily via abstraction of the acidic hydrogen with a recommended temperature independent rate of $4.5 \times 10^{-13} \mathrm{~cm}^{3}$ (molec s${ }^{-1}$ ) (Atkinson et al., 2006). The uncertainty of this rate coefficient is relatively large $(\Delta \log =$ 0.15 at $298 \mathrm{~K}$ (Atkinson et al., 2006)) because of experimental challenges (dimerization of FA). To our knowledge, this rate coefficient has not been determined below $298 \mathrm{~K}$. Theoretical calculations suggest, however, that the acidic (R1), dominant at ambient temperature, and formyl (R2) channels have opposite temperature dependence (Galano et al., 2002; Sun and Saeys, 2008).

$$
\begin{aligned}
\mathrm{HCOOH}+\mathrm{OH} & \rightarrow \mathrm{HCOO}+\mathrm{H}_{2} \mathrm{O} \\
& \rightarrow \mathrm{COOH}+\mathrm{H}_{2} \mathrm{O}
\end{aligned}
$$

This results in a relatively "flat" temperature profile near $298 \mathrm{~K}$ where the laboratory investigations were conducted but a strong negative temperature dependence at lower temperature. This will be examined in Sect. 4.3.

In contrast, the AA reaction with $\mathrm{OH}$ has been studied over a much wider temperature range. The reaction follows a mechanism similar to FA (Butkovskaya et al., 2004) and exhibits a negative activation energy. The temperature dependence remains uncertain and we use the IUPAC recommendation, $4.2 \times 10^{-14} \exp (855 / T) \mathrm{cm}^{3}\left(\right.$ molec s$\left.{ }^{-1}\right)$ ( $\Delta \log =0.15$ at $298 \mathrm{~K}$ ) (Atkinson et al., 2006), which is in excellent agreement with the two most recent determinations of this reaction rate coefficient (Butkovskaya et al., 2004; Huang et al., 2009).

\subsubsection{Dry deposition}

Dry deposition of oxidants and water soluble species is computed using a resistance-in-series model based on the formulation of Wesely (1989) implemented in GEOS-Chem by Wang and Jacob (1998). The dry deposition velocities of FA and AA depend on surface momentum and sensible heat fluxes, temperature, solar radiation as well as the effective Henry's constant of FA and AA $(\mathcal{H})$, which are calculated at a $\mathrm{pH}$ of 7 , a reasonable assumption for most surfaces (Wesely, 1989). We use the median of the reported measurements: $\mathcal{H}_{\mathrm{FA}}=5400 \mathrm{M} \mathrm{atm}^{-1}, \mathcal{H}_{\mathrm{AA}}=5350 \mathrm{M} \mathrm{atm}^{-1}$ (Sander, 1999).

\subsubsection{Wet deposition}

Wet deposition is thought to be the most important sink of FA and AA (Chebbi and Carlier, 1996). The GEOS-Chem wet deposition scheme includes scavenging of soluble tracers in convective updrafts, as well as rainout and washout of soluble tracers (Mari et al., 2000; Liu et al., 2001). We assume a rain $\mathrm{pH}$ of 5 and that the acids are fully retained at freezing, as with $\mathrm{HNO}_{3}$.

We modify the GEOS-Chem deposition scheme to include the uptake of FA and AA in ice clouds. Briefly, assuming equilibrium between the ice surface concentration $[X]_{\mathrm{s}}\left(\right.$ molec $\left.\mathrm{cm}^{-3}\right)$ and the gas-phase concentration $[X]_{\mathrm{g}}$ $\left(\right.$ molec $\left.\mathrm{cm}^{-3}\right)$, non-dissociative uptake and non competitive adsorption, $[X]_{\mathrm{s}}$ can be related to the surface area of ice $\left(S_{\text {ice }}\right.$ $\left.\left(\mathrm{cm}^{2} \mathrm{~cm}^{-3}\right)\right)$, the maximum number of molecules which can be adsorbed on the surface $\left(N_{\max }\left(\right.\right.$ molecules $\left.\left.\mathrm{cm}^{-2}\right)\right)$ and the fractional coverage $(\theta)$ by: 
$[X]_{\mathrm{s}}=S_{\text {ice }} \theta N_{\max }$

$\theta$ is given by the Hill-Langmuir equation:

$\theta=\frac{\frac{K}{N_{\max }}[X]_{\mathrm{g}}}{1+\frac{K}{N_{\max }}[X]_{\mathrm{g}}}$

where $K(\mathrm{~cm})$ is a temperature dependent partition coefficient: $K=\alpha \times \exp (\beta / T)$ with $\alpha_{\mathrm{FA}}=5.8 \times 10^{-11} \mathrm{~cm}, \alpha_{\mathrm{AA}}=$ $1.0 \times 10^{-10} \mathrm{~cm}$ and $\beta_{\mathrm{FA}}=6500 \mathrm{~K}, \beta_{\mathrm{AA}}=6600 \mathrm{~K}$ (Marécal et al., 2010; Crowley et al., 2010).

\subsubsection{Dust}

Field measurements have identified formate and acetate on collected mineral aerosols (Lee et al., 2000, 2002; Russell et al., 2002; Falkovich et al., 2004). Falkovich et al. (2004) found that formate and acetate were the most abundant mono carboxylic anions in dust particles and that their uptake was facilitated at higher relative humidity $(\mathrm{RH})$.

Consistent with these observations, efficient uptake of carboxylic acids on various components of dust (Usher et al., 2003) has been measured: FA on clay (montmorillonite) (Hatch et al., 2007) and $\mathrm{CaCO}_{3}$ (Al-Hosney et al., 2005); AA on $\mathrm{SiO}_{2}, \alpha-\mathrm{Al}_{2} \mathrm{O}_{3}, \alpha-\mathrm{Fe}_{2} \mathrm{O}_{3}$ (Carlos-Cuellar et al., 2003) and $\mathrm{CaCO}_{3}$ (Prince et al., 2008). Increased water enhance the capacity of the mineral dust to take up carboxylic acids (AlHosney et al., 2005; Hatch et al., 2007; Prince et al., 2008) but does not change the accommodation coefficient $(\gamma)$ significantly.

Surface saturation needs to be explicitly treated as it severely reduces the efficiency of this removal mechanism (Hatch et al., 2007). Accounting for the saturation limit, Hatch et al. (2007) estimated that up to $40 \%$ of gaseous AA could be removed during a dust storm.

In GEOS-Chem, dust is carried into four different size bins. Here we use emissions from the dust entrainment and deposition (DEAD) scheme (Zender et al., 2003; Fairlie et al., 2007). From Hatch et al. (2007), we use $\gamma_{\mathrm{FA}}=4 \times$ $10^{-4}$ and $\gamma_{\mathrm{AA}}=3 \times 10^{-4}$ for $\mathrm{RH}<30 \% ; \gamma_{\mathrm{FA}}=5.4 \times 10^{-4}$ and $\gamma_{\mathrm{AA}}=14 \times 10^{-4}$ for $\mathrm{RH} \geq 30 \%$. The dependence of surface saturation ( $S$ in $\mathrm{mg}($ acid $) / \mathrm{g}$ (dust)) on RH is approximated by fitting an exponential to Hatch et al. (2007) measurements: $S_{\mathrm{FA}}=2+4.7 \times\left(1-\exp \left(-8.6 \times 10^{-3} \times \mathrm{RH}\right)\right)$ and $S_{\mathrm{AA}}=2+5.8 \times\left(1-\exp \left(-2.6 \times 10^{-2} \times \mathrm{RH}\right)\right)$. Heterogeneous degradation of FA (Al-Hosney et al., 2005) and AA (Prince et al., 2008) to $\mathrm{CO}_{2}$ is not represented but may further enhance the uptake of FA and AA.

\subsection{Simulated distribution}

\subsubsection{Formic acid}

The total source of formic acid in the model is about $1200 \mathrm{Gmol} \mathrm{yr}^{-1}$ (Table 3). This is about twice as large as previous estimates (Ito et al., 2007; von Kuhlmann et al., 2003a).
Modeled FA sources are dominated by photochemical production from the oxidation of biogenic precursors. More than a third of the FA photochemical source stems from glycolaldehyde and hydroxyacetone via the Butkovskaya's mechanism (Butkovskaya et al., 2006a,b). These sources were not included in previous estimates and account for much of the difference (Table 3). Other important sources include isoprene ozonolysis (14\% of the photochemical production) and monoterpenes photooxidation $(6 \%)$. Acetylene is the dominant non-biogenic precursor $(6.5 \%)$.

Over three quarters of FA photochemical production is derived from isoprene photooxidation, many aspects of which remain uncertain. In particular, it is worth noting that the mechanism recently proposed by Peeters et al. (2009) results in large modifications of the distribution of isoprene photooxidation products determined from chamber experiments (including hydroxyacetone and glycolaldehyde). If correct, this could significantly affect the modeled budget of FA. Nevertheless, despite our incomplete knowledge of isoprene photooxidation, its representation in the GEOS-Chem mechanism is much more explicit than for most other biogenic volatile organic compounds. This probably results in an overestimation of the importance of isoprene as a precursor for FA as the photooxidation of other biogenic volatile organic compounds, such as the different monoterpenes, is much more simplified.

Direct emissions of FA are small $(\sim 15 \%)$ and dominated by terrestrial vegetation and biomass burning. Emissions from vehicles do not contribute significantly to the modeled FA budget, consistent with observations from de Gouw et al. (2005). Our modeled FA budget suggests, however, that more than $90 \%$ of $\mathrm{FA}$ is composed of modern carbon globally (Table S2). This percentage is lower in the northern mid and high latitudes, though FA is still predicted to be largely dominated by modern sources (Table S2), consistent with isotope studies in Europe (Glasius et al., 2001).

The enhancement in FA $(\Delta \mathrm{FA})$ in aged biomass burning plumes and its correlation with $\triangle \mathrm{CO}$ has frequently been used to derive emission factors from ground or satellite based observations (e.g. Paton-Walsh et al., 2005; Rinsland et al., 2007; Gonzàlez Abad et al., 2009). Our study suggests that FA is rapidly removed from the boundary layer by wet and dry deposition, so that little FA emitted or formed in the boundary layer is advected over long distances or transported into the free troposphere. Therefore $\triangle \mathrm{FA}$ observed in aged plumes is unlikely to represent direct emissions, as commonly assumed, but rather the production of FA from the photooxidation of biomass burning emitted precursors. Thus, $\Delta$ FA cannot be used, in general, to derive emission factors far away from emission regions.

FA sinks are dominated by depositions. Dust is not a significant sink globally but can result in a large decrease of acids in the vicinity of large deserts.

The modeled atmospheric lifetime of FA is 3.2 days, consistent with previous estimates (Chebbi and Carlier, 1996). 
Table 3. Modeled global budget of atmospheric formic and acetic acids (2004-2008 average). Previous estimates are indicated in parentheses.

\begin{tabular}{|c|c|c|}
\hline & Formic acid ( $\tau=3.2$ days) & Acetic acid ( $\tau=2.3$ days $)$ \\
\hline Total Sources $\left(\mathrm{Gmol} \mathrm{yr}^{-1}\right)$ & $1232\left(666^{\mathrm{a}}, 587^{\mathrm{b}}\right)$ & $1424\left(1550^{\mathrm{a}}, 1217^{\mathrm{b}}\right)$ \\
\hline \multirow[t]{2}{*}{ Photochemical production } & 1055 & 976 \\
\hline & $\left(370^{\mathrm{a}}, 370^{\mathrm{b}}\right)$ & $\left(1250^{\mathrm{a}}, 700^{\mathrm{b}}, 2000^{\mathrm{c}}\right)$ \\
\hline Biogenic & $917^{d}$ & $955^{\mathrm{d}}$ \\
\hline Anthropogenic & 138 & 21 \\
\hline \multicolumn{3}{|l|}{+ Biomass burning } \\
\hline Emissions & $177\left(296^{\mathrm{a}}, 217^{\mathrm{b}}\right)$ & $448\left(300^{\mathrm{a}}, 517^{\mathrm{b}}\right)$ \\
\hline Anthropogenic & 3.5 & 7 \\
\hline Biofuel Burning & $6.5\left(25^{\mathrm{b}}\right)$ & $114.5\left(274^{\mathrm{b}}\right)$ \\
\hline Biomass Burning & $32.5\left(174^{\mathrm{a}}, 183^{\mathrm{b}}\right)$ & $187\left(243^{\mathrm{a}}, 279^{\mathrm{b}}\right)$ \\
\hline \multirow[t]{2}{*}{ Cattle } & 39.5 & 39.5 \\
\hline & $\left(25-100^{f, g}\right)$ & $\left(4.2-16.8^{f}\right)$ \\
\hline Soil & 39 & 57 \\
\hline \multirow{2}{*}{ Terrestrial vegetation } & 56 & 43 \\
\hline & $\begin{array}{r}\left(122^{\mathrm{a}}, 125^{\mathrm{h}}, 33-166^{\mathrm{i}},\right. \\
\left.20-130^{\mathrm{j}}\right)\end{array}$ & $\left(56^{\mathrm{a}}, 25^{h}, 17-83^{\mathrm{i}}, 10-33^{\mathrm{j}}\right)$ \\
\hline Total Sinks $\left(\mathrm{Gmol} \mathrm{yr}^{-1}\right)$ & 1233 & 1426 \\
\hline Photochemical & 229.5 & 413 \\
\hline Dry deposition & 536 & 522 \\
\hline Wet deposition & 437.5 & 451.5 \\
\hline Dust & 30 & 39.5 \\
\hline
\end{tabular}

a von Kuhlmann et al. (2003a,b).

b Ito et al. (2007).

c Baboukas et al. (2000).

d Neglect biomass burning contribution to hydroxyacetone and glycolaldehyde.

e Sum of biomass burning and biogenic emissions.

${ }^{\mathrm{f}}$ Ngwabie et al. (2008).

$\mathrm{g}_{2} \mathrm{H}_{5} \mathrm{OH}+\mathrm{HCOOH}$.

${ }^{\mathrm{h}}$ Lathière et al. (2006).

j Kesselmeier et al. (1998).

The lifetime of FA in the boundary layer is about 1.6 days (excluding transport to the free troposphere).

The FA atmospheric mass is highest in the tropics $(\sim 60 \%$ of the global burden Table S2) as a result of large biogenic and biomass burning emissions (Fig. 1). Modeled mixing ratios in the Northern midlatitudes are low and follow the seasonal cycle of biogenic emissions.

\subsubsection{Acetic acid}

The total source of acetic acid is about $1400 \mathrm{Gmol} \mathrm{yr}^{-1}$ (Table 3). Emissions of AA account for about one third of AA sources. The difference with FA stems from much larger direct emissions from biomass and biofuel burning. Secondary production from anthropogenic sources or biomass burning is small. AA production has, however, been observed in biomass burning plumes. For instance, Yokelson et al. (2003) observed $\triangle \mathrm{AA} / \Delta \mathrm{CO}$ increase by as much as $9 \%$ in some biomass burning plumes and noted that the secondary production of AA exceeds the measured direct emissions.
This observation cannot, however, be generalized since other plumes did not exhibit production of AA (de Gouw et al., 2006; Yokelson et al., 2009, and references therein). Yokelson et al. (2009) also noted that the growth of FA and AA in the Yucatan biomass burning plumes cannot be accounted for by the photochemistry of their known precursors, pointing to unidentified high molecular weight precursors. The importance of these precursors as a source of FA and AA will be investigated in Sect. 4.2.

Photochemical production is dominated by the reaction of PA with $\mathrm{HO}_{2}(53 \%)$ and other peroxy radicals (24\%), with isoprene photochemistry and acetaldehyde oxidation the primary sources of PA. Our estimates are consistent with those of von Kuhlmann et al. (2003a) and Ito et al. (2007) but much lower than the estimate by Baboukas et al. (2000). von Kuhlmann et al. (2003a) pointed out that this is the result of the very high branching ratio for the production of AA from $\mathrm{PA}+\mathrm{HO}_{2}$ assumed by Baboukas et al. (2000), inconsistent with values reported in recent laboratory experiments (e.g., Dillon and Crowley, 2008). 


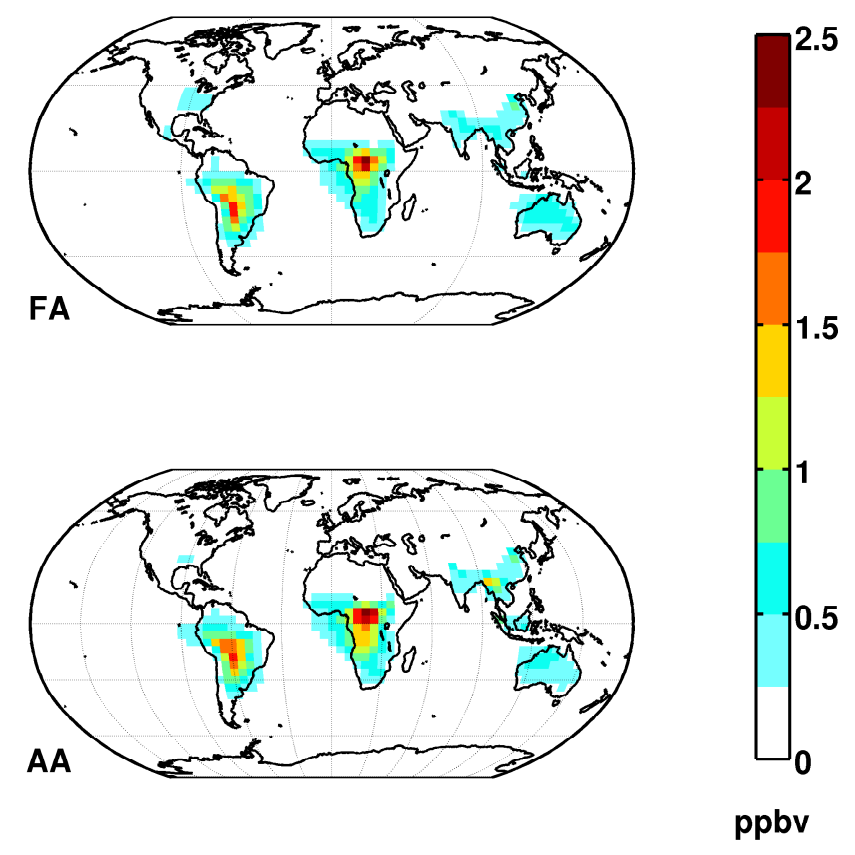

Fig. 1. Annual simulated distribution of FA and AA in the boundary layer. FA and AA maxima in the tropics reflect strong biogenic sources.

Similar to FA, deposition is the major sink of AA. Because AA is less soluble than FA and because its oxidation by $\mathrm{OH}$ is faster and has a negative temperature dependence, photooxidation of AA is much more important than for FA and contributes to the significantly shorter lifetime of AA in the atmosphere: 2.3 days (1.7 days in the boundary layer). AA is predicted to primarily consist of modern carbon globally (Table S3). The distribution follows patterns similar to FA with a stronger influence of biomass and biofuel burning.

\section{Comparison with observations}

In this section, we evaluate the GEOS-Chem simulation against upper tropospheric and total column measurements of FA by solar absorption spectrometry in the infrared using a Fourier transform spectrometer (FTS) as well as FA and AA aircraft measurements. The location of ground based stations, the ship cruises and aircraft-based measurements is indicated in 2 .

\subsection{FTS measurements}

FA can be measured by FTS using the Q-branch of the $v_{6}$ mode near $1105 \mathrm{~cm}^{-1}$. In this section, we use FA total columns retrieved by ground-based stations of the Network for the Detection of Atmospheric Composition Change (NDACC, http://www.ndacc.org/, Kurylo and Solomon (1990)) as well as during several cruises by the Ger- man vessel Polarstern in the Atlantic ocean (Velazco et al., 2005). We also use upper tropospheric FA profiles measured by the space-borne Atmospheric Chemistry Experiment FTS (Bernath et al., 2005). All retrievals use the revised spectroscopic parameters for FA (Vander Auwera et al., 2007) contained in the HITRAN 2008 spectral database (Rothman et al., 2009).

\subsubsection{Ground-based total column}

Solar spectra in the vicinity of the $v_{6}$ vibration have been obtained by several stations of the NDACC: Barcroft in the Inyo National Forest (California) at $3800 \mathrm{~m}$, Bremen in northwestern Germany, La Réunion $700 \mathrm{~km}$ east of Madagascar, Paramaribo on the coast of Suriname, Thule in northwestern Greenland, and Wollongong, $100 \mathrm{~km}$ south of Sydney. The different measurement sites and the cruise ship tracks are depicted in Fig. 2. Measurement uncertainty is estimated to be $\sim 19 \%$. The choice of the spectral microwindow used to retrieve FA could result in a systematic bias in the retrieved FA as large as $\pm 2.7 \times 10^{15}$ molec $\mathrm{cm}^{-2}$. A more detailed description of the FTS retrievals can be found in the Supplement (Figs. S1 to S4 and Table S1).

\section{Photooxidation of isoprene and other biogenic emissions: a major source of FA}

The FA seasonal cycle at the mid-latitude stations, Wollongong (Fig. 3a, see also Fig. S5), Bremen (Fig. 4b, see also Fig. S6) and Barcroft (Fig. 4c, see also Figs. S7 to S9) is consistent with a major source of FA from terrestrial biogenic emissions and their photooxidation. At Wollongong, for instance, FA and biogenic emissions peak simultaneously in January. In contrast, $\mathrm{CO}$ and $\mathrm{HCN}$ total columns generally peak around October, at the height of the biomass burning season (Fig. S5). At Barcroft, the strong correlation between FA and $\mathrm{CH}_{2} \mathrm{O}$ in the summer months (Fig. S7) also suggests a large influence of biogenic emissions on the FA budget. In contrast there is no correlation between FA and HCN. This interpretation is consistent with the conclusions of Zander et al. (2010) that FA seasonal variations above the Alpine plateau are the result of natural processes.

At all sites, the model predicts large contributions of biogenic photooxidation to the FA budget. The model performs best in regions and time periods impacted by large isoprene emissions such as in Wollongong (Fig. 3a) and La Réunion (Fig. 4a). Interestingly, the model predicts a biogenic peak in FA in May at La Réunion later than the maximum in isoprene emission in Southern Africa (Otter et al., 2002). Intense precipitations from January to April over La Réunion may explain this delay by efficiently scavenging FA (leading to a minimum in the modeled FA in January). As the climate becomes drier in May, the atmospheric lifetime of FA increases resulting in higher FA total columns in spite of lower 


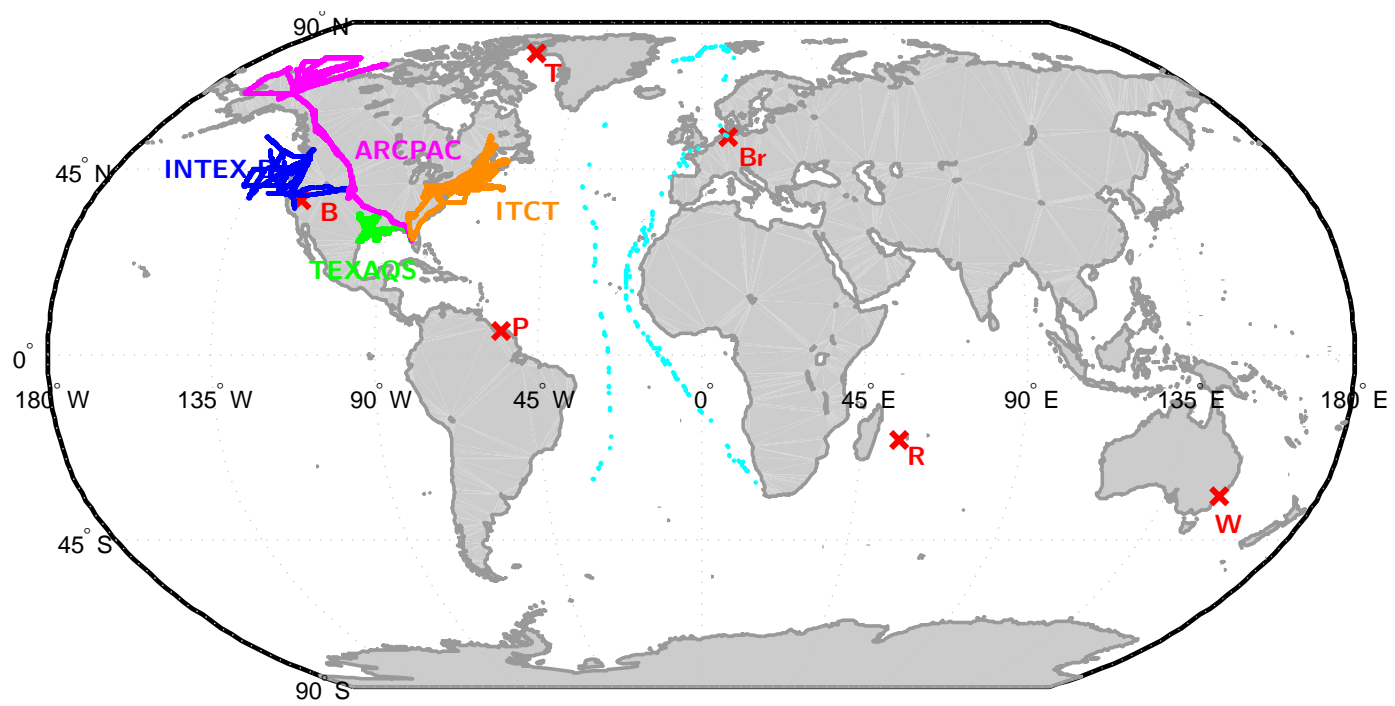

Fig. 2. Locations of the measurement sites used in this study. Red crosses: FTS ground stations (B: Barcroft, Br: Bremen, P: Paramaribo, R: La Réunion, T: Thule, W: Wollongong). Cyan dots: ship cruises. Blue, Magenta, Yellow and Green dots: aircraft missions flight tracks.

isoprene emissions. This illustrates the complicated interplay between FA sources and sinks in the tropics. The model suggests La Réunion is especially sensitive to this effect as the modeled FA total column is dominated by transport from Madagascar and Southern Africa.

In contrast, the model greatly underestimates FA at Bremen (Fig. 4b) and Barcroft (Fig. 4c). These stations exhibit a marked biogenic signature but are located in regions with lower isoprene emissions. This likely reflects a missing biogenic precursor of FA in the model. In these regions, FA production may be promoted by seasonal biotic emissions from cattle and crop farming (Karl et al., 2009) associated with elevated ozone due to anthropogenic activities. The anthropogenic contribution to FA is predicted to be low at both sites (less than 5\%) consistent with the seasonal profile of FA and previous isotope measurements in Europe (Glasius et al., 2000, 2001).

We note that Barcroft data must be interpreted cautiously as the complicated topography of the region is not resolved in the model. In particular summer FA total columns show evidence for boundary layer incursions which are not captured at the coarse resolution used in this study. However, $\mathrm{CH}_{2} \mathrm{O}$ seasonality is surprisingly well-captured in the model despite a low-bias in the summer (Fig. S8). Therefore, meteorology alone is unlikely to explain the large discrepancy between the model and the data over this site, and sources from the Central Valley ( $150 \mathrm{~km}$ to the west of Barcroft) are likely underestimated.

\section{Missing biomass burning precursors}

Evidence for a large but more localized and seasonal biomass burning source of FA can be found in the Wollongong and $\mathrm{La}$ Réunion records (Figs. 3a and 4a). In La Réunion, FA peaks in October. This peak is also observed in $\mathrm{CO}$ and $\mathrm{CH}_{2} \mathrm{O}$ FTS measurements at the same location and is associated with biomass burning in Southern Africa (CO) and Madagascar ( $\mathrm{CO}$ and $\mathrm{CH}_{2} \mathrm{O}$ ) (Vigouroux et al., 2009). In Wollongong, the anomalously high FA total column measured in December 2006, the largest on the record, is also associated with biomass burning, since (a) it clearly precedes the biogenic peak in FA observed in other years, (b) very large bush fires burned over 1 million acres from December 2006 to January 2007 in the Victorian Alps $\sim 450 \mathrm{~km}$ southwest of Wollongong, and (c) anomalously high $\mathrm{CO}$ and HCN columns are recorded during the same time period (Fig. S5). This is consistent with the work of Paton-Walsh et al. (2005) who reported a significant correlation between aerosol optical depth and FA at the same site during bush fires from 2001 to 2003 and inferred that biomass burning could result in a strong enhancement in FA total column at this site.

The model captures the timing of the biomass burning contribution to the FA column well but underestimates FA during biomass burning periods. The coarse resolution of the model is likely to contribute to this discrepancy due to the dilution of biomass burning plumes. However, the systematic discrepancy on a multi-year average at La Réunion may also indicate missing biomass burning sources of FA.

The discrepancy for marine sites (cruise (Fig. 5) and Paramaribo (Fig. 4d)) also hints at a missing biomass burning source of FA. Air masses affected by biomass burning 


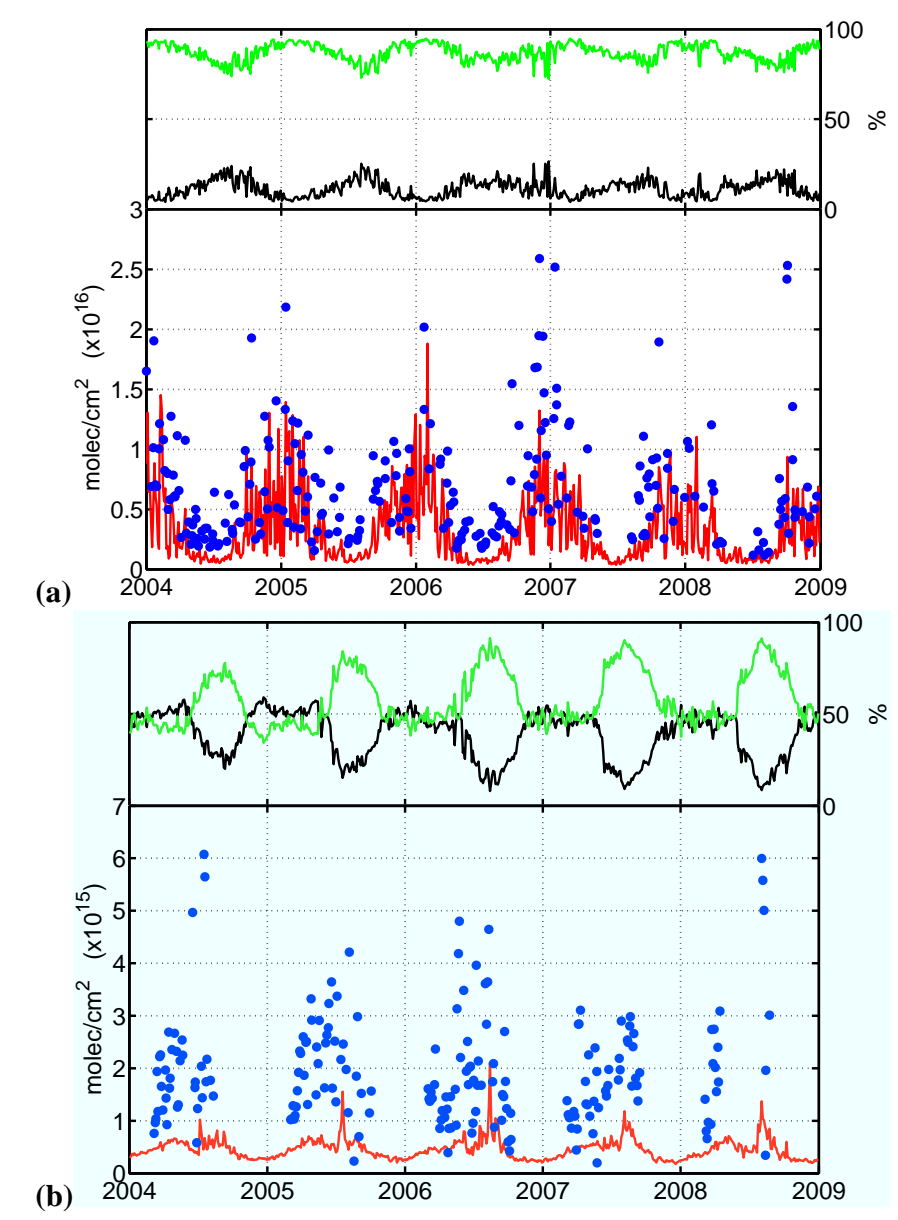

Fig. 3. The observed seasonal cycle of FA total column (blue, lower panel) is well captured by the model at (red, lower panel) at Wollongong, Australia $\left(34.5^{\circ} \mathrm{S}, 150^{\circ} \mathrm{E}, 20 \mathrm{~m}\right.$ a.s.l., (a)) and is consistent with a strong biogenic influence (green, upper panel). This is not the case in the high latitude site at Thule, Greenland $\left(76.53^{\circ} \mathrm{N}\right.$, $68.75^{\circ} \mathrm{W}, 220 \mathrm{~m}$ a.s.l., (b)) where model under predicts measured FA. Upper panel: modeled contribution of biogenic sources (green: emission + photochemical production) and biomass burning (black: emissions + photochemical production) to FA total column. Lower panel: modeled (red) and measured (blue) FA total column. Measurements and model are averaged over a two day time period.

emissions are known to be advected aloft from Africa to South America and their impact has been measured over Paramaribo during the dry season from August to November (Peters et al., 2004; Petersen et al., 2008). High CO measured in the tropics during cruises is also well correlated with FA ( $R=0.64$, Fig. S10). The lifetime of FA is, however, incompatible with a large contribution of directly emitted FA to the FA total column over Paramaribo (transport time from Africa to Paramaribo has been estimated at 10 days by Peters et al. (2004)) and suggests a missing long-lived precursor from biomass burning. Sources of FA and AA from marine emissions are also likely to be underestimated since the model predicts surface concentrations which are 2 to 5 times lower than measurements made during cruises by Arlander et al. (1990) and Baboukas et al. (2000).

\section{A local source in the polar regions}

FA and AA account for a large fraction of the water-soluble organic carbon (gas + particle) over snow in polar regions (Anderson et al., 2008). Better constraints on the budget of FA and AA in these regions may help understand the large variations in FA and AA observed in the ice core record in the last 100000 years (Legrand and De Angelis, 1996). These variations have been tentatively attributed to changes in the biosphere or biomass burning activity in boreal regions (Fuhrer and Legrand, 1997; Eichler et al., 2009).

Measured FA over Thule is about one order of magnitude lower than in Wollongong (Fig. 3b). The largest FA total columns are measured in the summers of 2004 and 2008. Both these periods are characterized by exceptional biomass burning in boreal regions (in North America in 2004 and in Asia in 2008) (Giglio et al., 2010), consistent with the hypothesis that FA anomalies may reflect large biomass burning events. In the absence of local sources, the modeled FA column is dominated by transport. This is reflected in the modeled vertical distribution of FA peaking in the free troposphere. The model predicts a strong seasonal cycle with maximum during the boreal summer, corresponding to the largest biogenic and biomass burning emissions. The model underestimates FA total column by a factor of 2 to 5 . This discrepancy may in part reflect insufficient biomass burning emissions (Andreae and Merlet, 2001). We also note that the model predicts very low concentrations of FA at the surface $(\sim 10 \mathrm{pptv})$. This is in sharp contrast with the measurements of Anderson et al. (2008) which report $\sim 1 \mathrm{ppbv}$ of water-soluble organic carbon (primarily FA and AA) over Summit at $1.5 \mathrm{~m}$ above the snow. This discrepancy between model and observation in Thule may thus reflect missing local sources. Indeed, Dibb and Arsenault (2002) reported surface concentrations of FA and AA measured in the Arctic could not be sustained by transport alone but required a large source from snow photochemistry.

\section{Missing winter sources}

Mid latitude and low altitude sites (Bremen, Wollongong) show larger relative biases between the model and the data during the winter (Figs. 3a and $4 \mathrm{~b}$ ). This may point to large missing anthropogenic sources of FA (Talbot et al., 1988). Alternatively leaf decay may also contribute to the FA sources in the winter months (Kesselmeier et al., 1998). A missing biogenic contribution would be consistent with isotope measurements which showed that FA and AA are primarily made of modern carbon even in the winter (Glasius et al., 2001). 
(a)

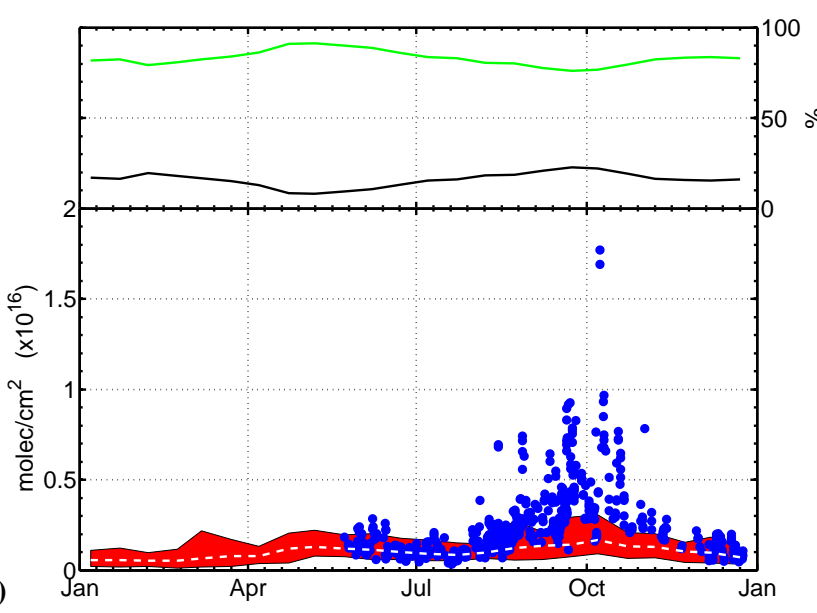

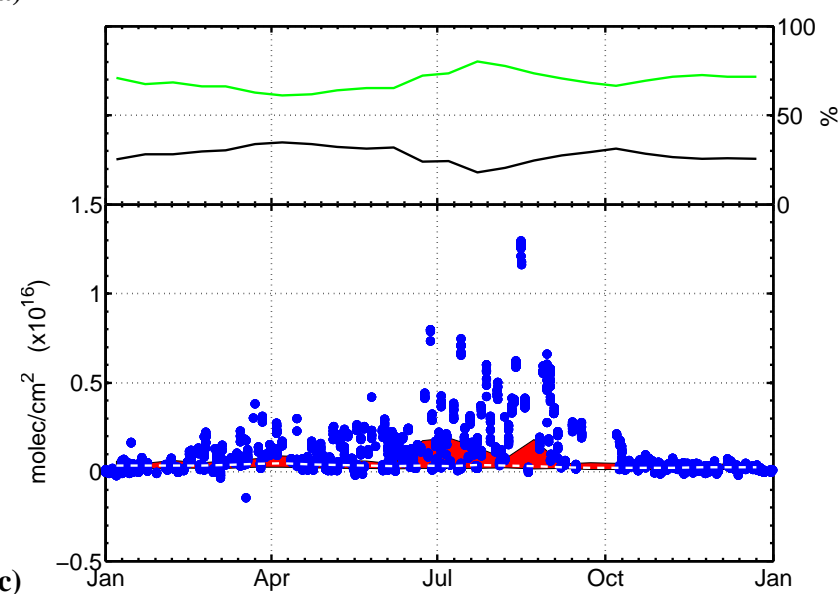

(b)

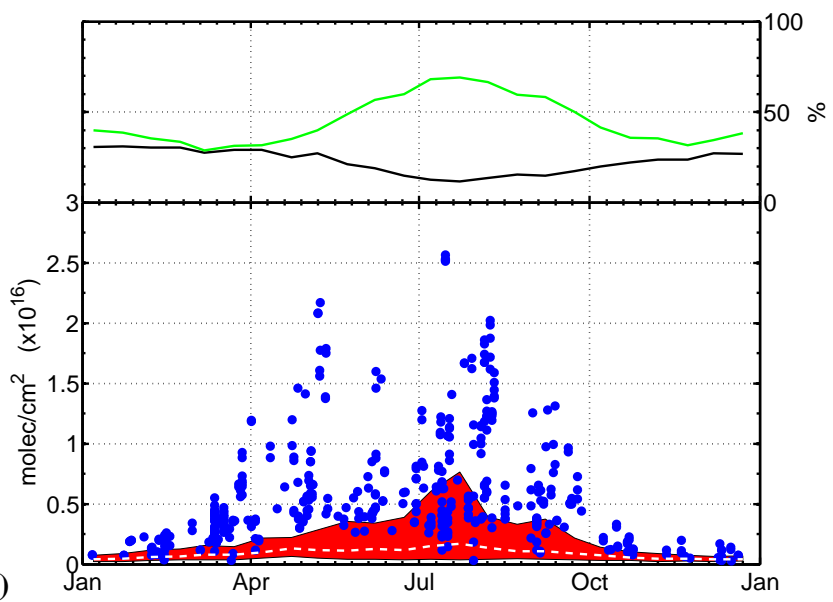

(d)

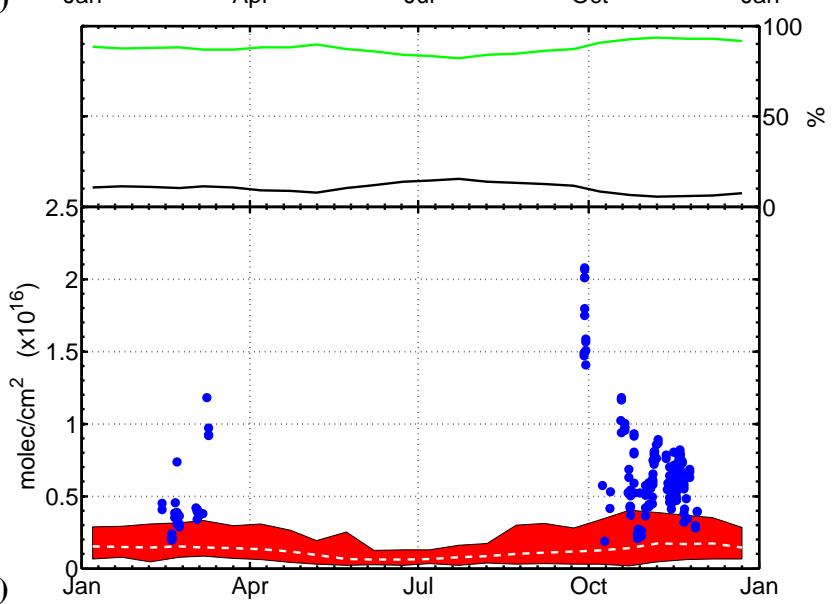

Fig. 4. (a) La Réunion, France $\left(-20.9^{\circ} \mathrm{N}, 55.5^{\circ} \mathrm{E}, 10 \mathrm{~m}\right.$.as.1.). Measurements are from campaigns in 2004 (Aug-Oct), 2007 (May-June; Aug-Oct) and 2009 (May-Dec) and (b) Bremen, Germany (53.1 ${ }^{\circ}$ N, $8.9^{\circ}$ E, $27 \mathrm{~m}$ a.s.1.). Measurements are from 2002 to 2010. (c) Barcroft, United States $\left(37.6^{\circ} \mathrm{N},-118.2^{\circ} \mathrm{E}, 3800 \mathrm{~m}\right.$ a.s.1.). Measurements are from campaigns in 1994 (Aug), 1998 (Oct-Dec), 1999 (Jan-Jul), 2000 (Oct-Dec), 2001 and 2002 (Jan-Aug) and (d) Paramaribo, Suriname (5.8 ${ }^{\circ} \mathrm{N}-55.2^{\circ} \mathrm{W}, 23 \mathrm{~m}$ a.s.1.). Measurements are from campaigns in 2004/2006 (Oct-Nov), 2005/2007 (Feb-Mar; Sep). Upper panels: same as Fig. 3. Lower panel: comparison between modeled and measured FA total columns. Individual total column measurements are indicated with blue dots. The 2004-2008 model range is indicated by the red shaded area and the model mean by the white dashed line.

\subsubsection{ACE-FTS}

The Atmospheric Chemistry Experiment (ACE) is a Canadian satellite that was launched by NASA on on $12 \mathrm{Au}-$ gust 2003. FA is measured by high spectral resolution $\left(0.02 \mathrm{~cm}^{-1}\right)$ FTS operating from 2.2 to $13.3 \mu \mathrm{m}$. Using solar occultation, the altitude profile of temperature, pressure and various chemical compounds, including FA, $\mathrm{CO}$ and $\mathrm{C}_{2} \mathrm{H}_{2}$ are determined between $85^{\circ} \mathrm{N}$ and $85^{\circ} \mathrm{S}$. Here, we are using version 3.0 of the ACE-FTS Level 2 data product.

Rinsland et al. (2006) and Gonzàlez Abad et al. (2009) have used the ACE-FTS spectra to retrieve mid and upper tropospheric FA. Even though most FA is located at low altitude and thus cannot be observed by ACE-FTS, these upper atmospheric profiles provide insights into the sinks, sources and transport of FA.
Figure 6 shows the average distribution of FA measured by ACE-FTS from 2004 to 2008. FA is highest from 10 to $50^{\circ} \mathrm{S}$, probably reflecting large biogenic sources. The Northern hemisphere exhibits lower FA mixing ratios on average. FA mixing ratios decrease rapidly with altitude and away from the source region. High mixing ratios observed at high altitudes in the Southern Hemisphere may indicate efficient transport of FA or, more likely, its precursors from the boundary layer to the free troposphere.

The model captures mid tropospheric FA in the tropics and Southern mid latitudes relatively well. It is biased low north of $40^{\circ} \mathrm{N}$ (Fig. 7), mirroring the low modeled concentration of FA in the planetary boundary layer (Fig. 1) and consistent with the large underestimation of FA total column over Bremen. The model is biased high south of $50^{\circ} \mathrm{S}$. This region experiences among the lowest concentrations of FA and it is unclear how significant this discrepancy is. 


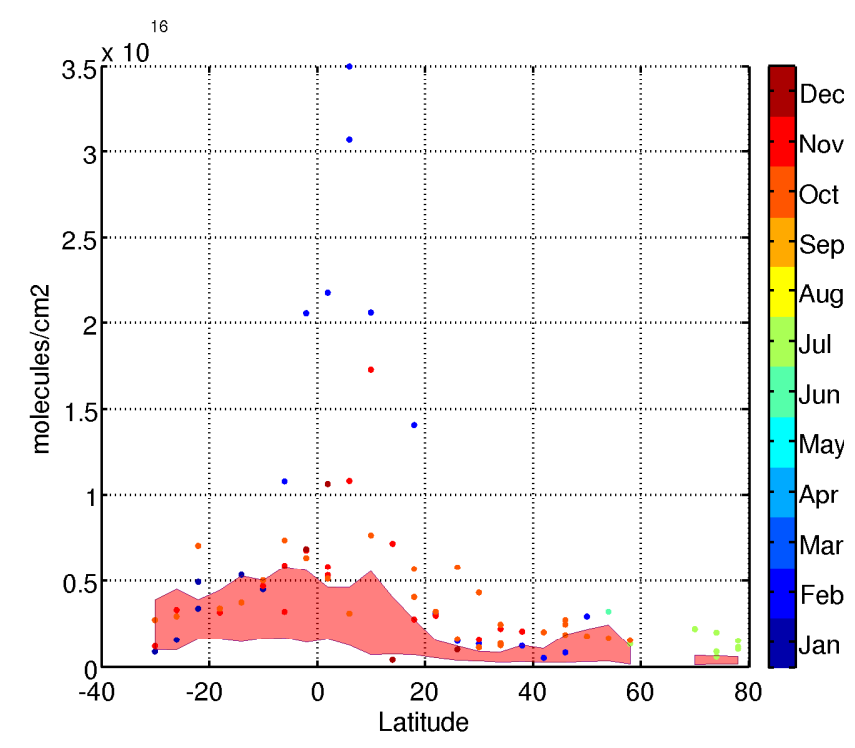

Fig. 5. Monthly FA total column measured during cruises in the Atlantic ocean in 1996, 1999, 2000, 2002, 2003 and 2005 (dots). The 2004-2008 model monthly mean range is indicated by the red shaded area. FA maximum in the tropics reflects biomass and biogenic sources.

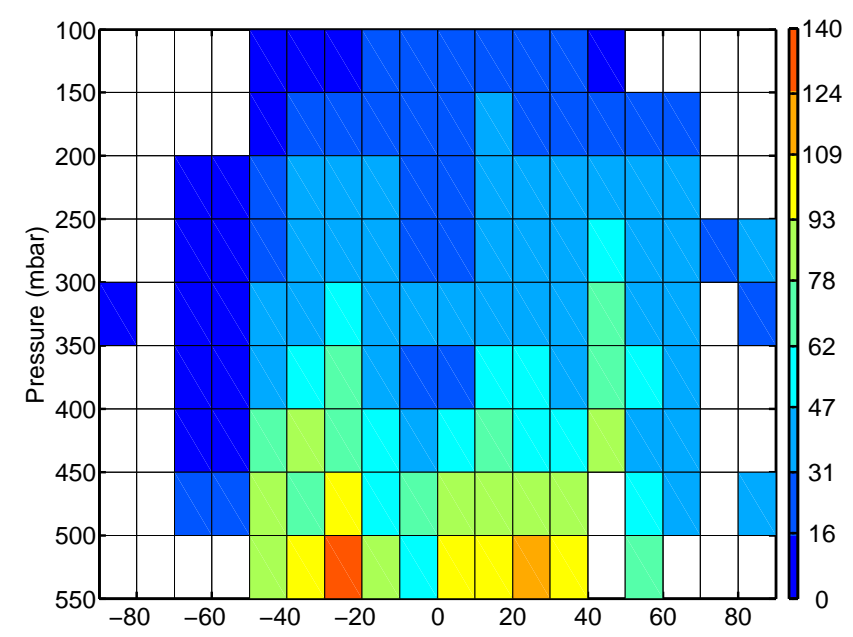

Fig. 6. Measured distribution of FA (pptv) by ACE-FTS from 2004 to 2008. Median of FA measurements is calculated in $10^{\circ}$ latitude 50 mbar bins. Only cells with more than ten measurements are shown.

The model greatly underestimates the measured vertical gradient of FA in the free troposphere, underestimating FA at low altitude and overestimating it at high altitude (Fig. 7). The correlation plot between FA and CO reveals possible reasons for this discrepancy (Fig. 8). The model overestimates FA at low CO (40 to $60 \mathrm{ppbv}$ ) which primarily reflects the high bias of the model at high altitude where most of the ACE-FTS measurements are taken. ACE HCN measurements (not shown) imply that air masses with $\mathrm{CO}$ mix-

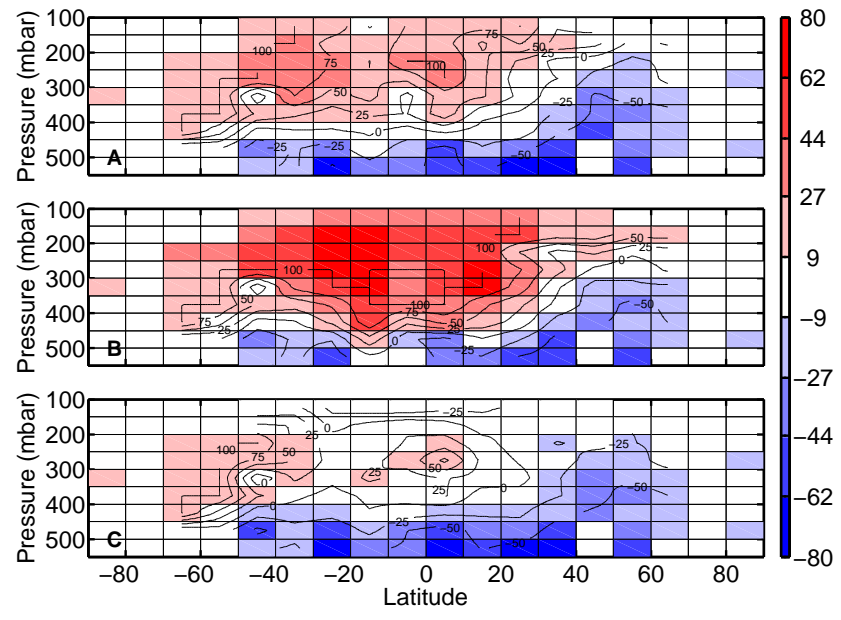

Fig. 7. Comparison of the simulated FA with observations by ACEFTS suggests an altitude-dependent error. Increasing the reaction rate of $\mathrm{OH}$ with FA reduces the model high-bias in the upper troposphere (C) while injection of biomass burning in the free troposphere provides little improvement in the middle troposphere while degrading FA simulation in the upper troposphere (B). Absolute difference between the model and the ACE-FTS measurement is shown in pptv with contours indicating the relative difference in $\%$ ((model-measurement)/measurement). Cells with no measurements are grayed. Panel (A) shows the comparison for the reference run (R1), Panel (B) for R2b and Panel (C) for R4 (see Sect. 4). The model is sampled at the location and time of the ACE-FTS measurement.

ing ratios greater than $160 \mathrm{ppbv}$ are strongly influenced by fresh biomass burning emissions. This is in part captured by the model which shows a strong enhancement of FA in this regime. The largest discrepancy is found for values of $\mathrm{CO}$ ranging from 120 to $150 \mathrm{ppbv}$. These air masses exhibit a weak biomass burning signature and are primarily located in the lower free troposphere at high northern latitudes. These air masses may be affected by boundary layer air, carrying high mixing ratios of FA or its precursors of biogenic or anthropogenic origins. Alternatively, they may be associated with aged biomass burning, which would support the existence of long-lived biomass burning precursors of FA.

\subsection{Aircraft measurements by mass spectrometry}

From the previous section, large sources of FA appears to be missing in the Northern Hemisphere mid latitudes. Here we present data from several aircraft missions over North America to gain insights on these missing sources. We use measurements from the Intercontinental chemical transport experiment (INTEX-B/IMPEX April to May 2006 with a focus on the transport of pollution from Asia to the United States over the Pacific, Singh et al., 2009), the Second Texas Air Quality Study (TexAQS II - August to October 2006 Parrish et al., 2009), the Intercontinental Transport and Chemical Transformation experiment (ITCT $2 \mathrm{k} 4$ campaign over 


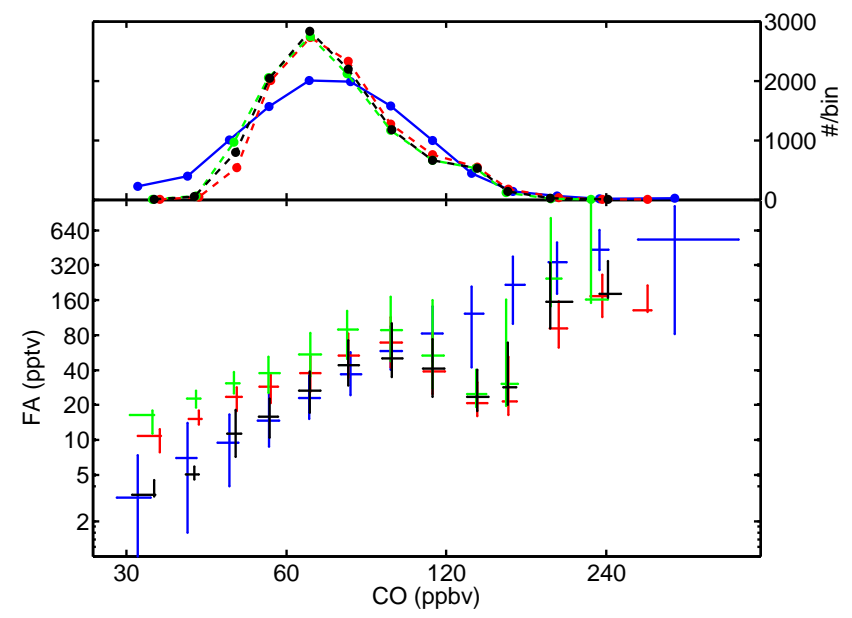

Fig. 8. The correlation between $\mathrm{CO}$ and FA observed by ACEFTS (blue crosses) in the free troposphere is not well-captured by the model (green, red and blue crosses), suggesting a missing secondary source. Lower panel: correlation plot between FA and CO (lower panel) for the measurements (blue) and the model: R1 (red), R2b (green), R4 (black). Upper panel: distribution of measured and modeled CO. The extent of the error bars indicate the 25 and 75 percentiles. The model is sampled at the location and time of the ACE-FTS measurement.

the Northeastern United States, Fehsenfeld et al., 2006) and the Aerosol, Radiation and Cloud Processes Affecting Arctic Climate study (ARCPAC 2008 over Alaska (Warneke et al., 2009)). FA and AA were measured by Chemical Ionization Mass Spectrometry during INTEX-B Crounse et al., 2006) and AA was measured by PTRMS during ITCT 2k4, ARCPAC 2008 and TexAQS II de Gouw and Warneke, 2007. Even though FA was not measured during these missions, it can be expected to correlate very well with AA (e.g., $R=0.9$ for INTEX-B).

The model underestimates AA and FA in all missions, consistent with total column observations in the Northern mid and high latitudes (Bremen and Thule). Missions closer to large biogenic or anthropogenic sources (ITCT 2k4 and TexAQS II) exhibit a smaller discrepancy than INTEX-B (impacted by aged Asian pollution) or ARCPAC 2008 (impacted by biomass burning). This suggests a large missing longlived precursor of FA and AA. Consistent with this hypothesis, air masses exhibiting a strong Asian pollution signature (as defined by Dunlea et al., 2009) exhibit a marked enhancement in FA and AA mixing ratio over other air masses sampled over the Pacific (Table 4). Since FA and AA emitted or formed in Asia are expected to be washed out as air is lifted out of the boundary layer, this enhancement hints at a secondary production of both acids. The correlation of FA with the organic fraction of the aerosols $(R=0.83$, Fig. 9), which are predominantly of secondary origin (Dunlea et al., 2009) is consistent with this hypothesis. Similarly, in ARCPAC 2008, a strong correlation of AA with black carbon

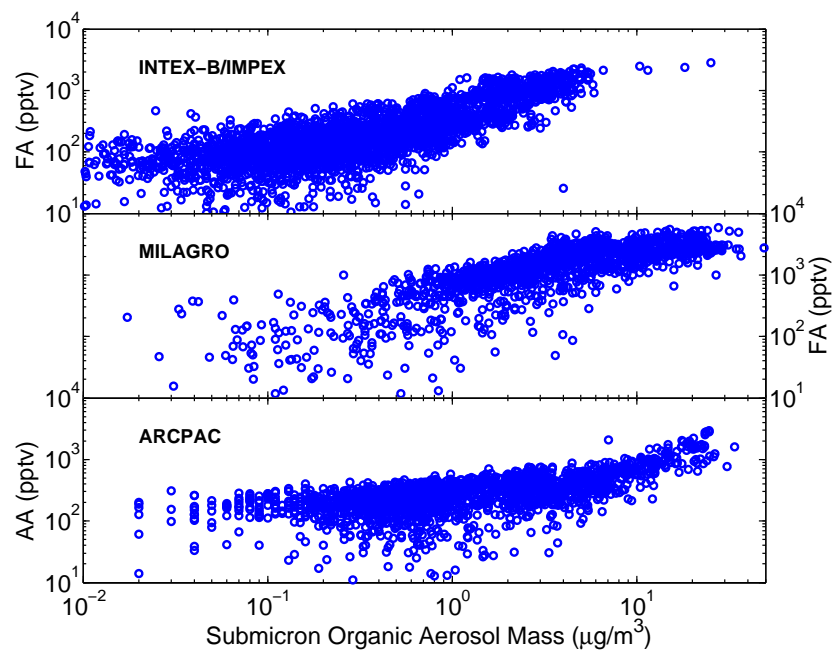

Fig. 9. In-situ measurements show strong correlation of FA and AA with the abundance of organic aerosol over the West Coast of the United States and the eastern Pacific (INTEX-B), in urban environments (MILAGRO) as well as in arctic regions (ARCPAC).

$(R=0.86)$ and the organic content of the aerosol $(R=0.82)$ hints at missing sources of AA from biomass burning.

Unrepresented precursors of FA and AA could also account for some of the discrepancy in INTEX-B (e.g. Sinreich et al., 2010). The discrepancy in the marine boundary layer for both acids is similar to the one reported by Baboukas et al. (2000) in the Atlantic ocean. Modeled marine sources of FA are a negligible fraction of FA photochemical production $(\sim 2.5 \%)$ reflecting the low emissions of FA precursors. This is not true for AA as acetaldehyde emissions from marine sources are large, resulting in $\sim 8.5 \%$ of AA production over the ocean. The marked maximum in FA total column in the tropics is, however, consistent with an important role of transport from the continents (Fig. 5).

INTEX-B measurements over the California Central Valley (Table 4) also confirm that cattle and/or crop farming is accompanied by very large mixing ratios of FA and AA (5 times greater than in Asian plumes and 10 times greater than in the Pacific free troposphere). In contrast with measurements taken over the Pacific, AA appears to be produced/emitted more efficiently than FA in this environment.

Comparisons between the model and the data show lower discrepancies for TexAQS II and ITCT 2k4( 2-3x, Fig. 10a and 10b). Correlations with anthropogenic markers (benzene: $R=0.5$ for TexAQS II, $R=0.75$ for ITCT $2 \mathrm{k} 4$; methoxyperoxyacetylnitrate: $R=0.85$ for ITCT $2 \mathrm{k} 4$ ) suggests a source of AA may be associated with anthropogenic processes. 
Table 4. The increase in the median measured (m) FA and AA in polluted air observed during INTEX-B/IMPEX reflects the importance of secondary sources in the budget of FA and AA. These sources are missing from the model (M). $\alpha$ is the slope of the linear fit: AA $=\alpha \mathrm{FA}+\beta$ calculated using York's method (York et al., 2004) for the measurement (ordinary least square for the model). Characterization of the air masses follows the approach of Dunlea et al. (2009).

\begin{tabular}{lllllll}
\hline & \multicolumn{2}{c}{$\mathrm{FA}(\mathrm{pptv})$} & $\mathrm{AA}(\mathrm{pptv})$ & \multicolumn{2}{c}{$\alpha \pm 1 \sigma\left(R^{2}\right)$} \\
\hline & $\mathrm{m}$ & $\mathrm{M}$ & $\mathrm{m}$ & $\mathrm{M}$ & $\mathrm{m}$ & $\mathrm{M}$ \\
\hline $\begin{array}{l}\text { Free troposphere } \\
\text { (Asian pollution) }\end{array}$ & 296 & 26 & 193 & 25 & $0.37 \pm 0.16(0.53)$ & $0.42(0.37)$ \\
$\begin{array}{l}\text { Free troposphere } \\
\text { (pristine + dilute Asian pollution) }\end{array}$ & 108 & 26 & 86 & 26 & $0.62 \pm 0.23(0.52)$ & $0.54(0.51)$ \\
$\begin{array}{l}\text { Boundary layer } \\
\text { (California Central Valley) }\end{array}$ & 1291 & 81 & 906 & 62 & $1.59 \pm 0.16(0.63)$ & $0.40(0.91)$ \\
\hline
\end{tabular}

\subsection{Summary of model-measurement comparisons}

The comparisons between measurements and model results have revealed that:

1. the model captures FA concentration and seasonality in regions with large biogenic emissions (ACE-FTS in the tropics, Wollongong, La Réunion)

2. FA and AA concentrations are largely underestimated when biomass burning (ARCPAC 2008, ACE-FTS, La Réunion) or anthropogenic influences (Bremen, INTEX-B) are strong. However, even in these instances, FA and AA seasonality (Bremen) suggests that a large fraction of FA and AA is associated with emission and photooxidation of biogenic compounds.

3. The rapid decrease in FA with altitude in the upper troposphere is not captured by the model.

4. FA and AA are greatly underpredicted in polar regions and in Northern midlatitude regions impacted by anthropogenic activities.

These observations are consistent with major secondary sources of FA and AA missing in the model. In the following, we use a series of sensitivity runs to examine the criteria a secondary source of FA and AA must meet to help bridge the gap between the model and the data. The reference simulation described in this section is referred to as $\mathrm{R} 1$ hereafter.

\section{Sensitivity study}

\subsection{Biomass burning injection height}

As a default in GEOS-Chem, biomass burning emissions are solely released in the boundary layer. However observations have shown that major fires can inject emissions well above the boundary layer (e.g. de Gouw et al., 2006; Vigouroux et al., 2009). Several modeling studies have also shown that observations of $\mathrm{CO}$ and aerosols downwind of fires could be best explained when a large fraction of the fire emissions is released above the boundary layer (e.g. Turquety et al., 2007). Injection of FA/AA or their precursors outside of the boundary layer is of great importance in their budget. Indeed a fast transport of carboxylic acids out of the boundary layer increases their lifetime by reducing the dry deposition sink and results in a large increase in their net lifetime. This in turn results in enhanced transport of FA and AA on larger scales. Furthermore biomass burning has been associated with a reduction of low-level precipitation (e.g. Andreae et al., 2004) which may further increase carboxylic acid lifetime.

Several studies have associated enhancements of FA in the free troposphere to biomass burning (Gonzàlez Abad et al., 2009). Here we examine whether injection of biomass burning emissions outside of the boundary layer can help bridge the gap between between model and observations at high CO. We use two different scenarios. In the first one (R2a), $60 \%$ of the biomass burning is emitted in the boundary layer while $35 \%$ is emitted in the mid troposphere (from the top of boundary layer to $400 \mathrm{hPa}$ ) and $5 \%$ in the upper troposphere ( $400 \mathrm{hPa}$ to $200 \mathrm{hPa}$ ). In the second scenario (R2b), we adopt one of the scenarios used by Turquety et al. (2007) to investigate biomass burning over North America with $40 \%$ of the biomass burning emissions in the boundary layer, $30 \%$ in the mid troposphere and 30\% in the upper troposphere. Since our goal is to examine the sensitivity of free tropospheric FA to biomass burning injection height, modifications of the injection height are applied globally, an important simplification (Val Martin et al., 2010, and references therein). Furthermore we assume that EF for FA and AA are independent of the the biomass burning injection height. This is another important simplification since (a) the injection of biomass burning in the free troposphere strongly depends on the fire intensity, and (b) EF for FA and AA exhibit some correlation with the modified combustion efficiency (MCE), an indicator of the combustion type (flaming or smoldering). Therefore, a more 


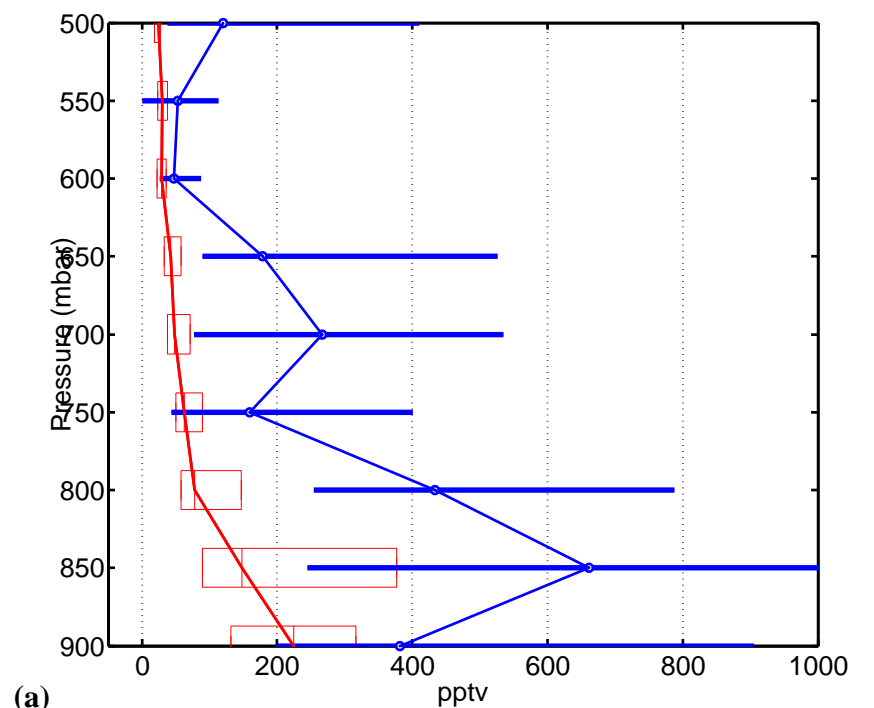

(a)

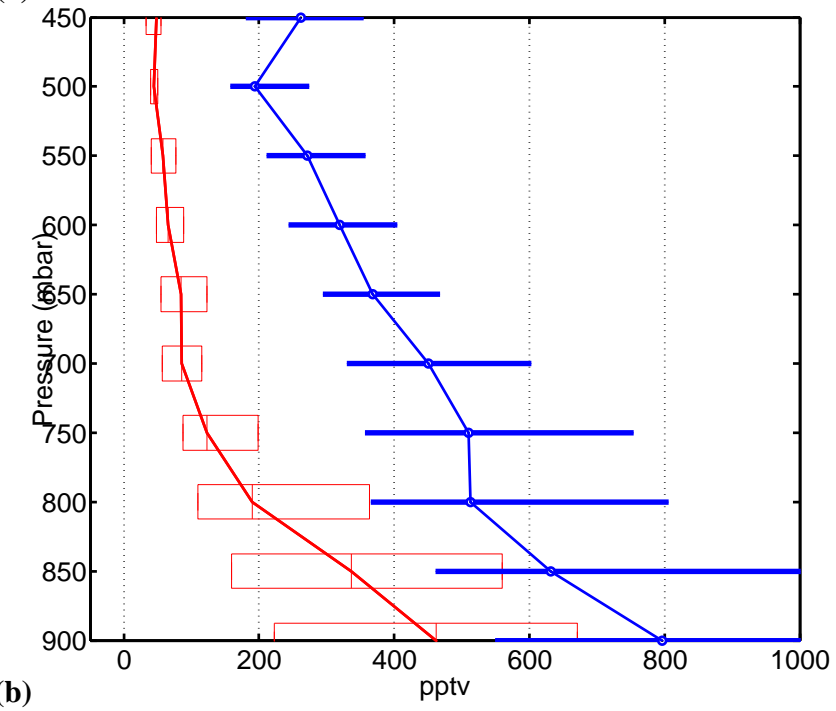

Fig. 10. (a) TexAQS II and (b) ITCT $2 k 4$. Comparison between measured (blue) and modeled (red) vertical AA profiles. The box (thick line) extent represents the $25 \%$ and $75 \%$ percentiles.

quantitative study of the importance of biomass burning in the FA and AA budget would require an explicit description of the relationship between MCE and EF as well as MCE and injection height.

Both scenarios lead to an enhancement of FA in the mid troposphere (by 10\% for R2a (not shown) and by 35\% for R2b (Fig. 7 panel b)). The increase is especially large at high $\mathrm{CO}$, greatly reducing the discrepancy between the model and the measurements (Fig. 8). This is remarkable since biomass burning emissions of FA and its precursors account for a relatively small fraction of FA sources in the model. This disproportionate effect highlights the strength of boundary layer sinks of FA which greatly hinder its transport to the free troposphere. The increase in FA induced by both scenarios is, however, insufficient to bridge the gap between the model and the data in the lower troposphere. In particular, it has no effect on the modeled FA in air masses with $\mathrm{CO}$ mixing ratios ranging from 120 to $150 \mathrm{ppbv}$. This is not surprising if these air masses are associated with aged biomass burning, as FA sinks (photooxidation and wet deposition) are faster than for $\mathrm{CO}$. In contrast, the injection of FA into the free troposphere significantly amplifies the discrepancy between the model and the measurements in the upper troposphere. The very long lifetime of FA in the upper troposphere is responsible for this strong sensitivity. In R2b, FA is increased by almost 50\% in the upper troposphere compared to the reference run, resulting in large discrepancies for $\mathrm{CO}$ between 40 and 120 ppbv (Fig. 7).

These observations suggest that the distribution of FA in the free troposphere is only sensitive to biomass burning injection height for fresh biomass burning plumes. As FA is removed from the free troposphere faster than $\mathrm{CO}$, the correlation between FA and $\mathrm{CO}$ across the whole $\mathrm{CO}$ range can only be sustained if the photooxidation of long-lived unrepresented compounds (i.e., poorly soluble and reactive) produces FA. However, if such a source exists, the observed vertical gradient of FA indicates a large sink is missing from the model in the upper free troposphere.

\subsection{Secondary source of FA and AA and organic aerosol aging}

The positive correlation of FA and AA with submicron organic aerosol observed in several aircraft campaigns (Fig. 9) hints at a possible relationship between FA and AA production and aerosol aging, i.e., processes affecting aerosol composition.

Aerosol composition is very dynamic as evidenced by the positive correlation between the oxygen to carbon ratio and the residence time of aerosols (DeCarlo et al., 2008; Capes et al., 2008). Near sources, aging is thought to be dominated by gas-phase oxidation of semivolatiles (a), while, for longer residence time, heterogeneous oxidation (b) may become important (DeCarlo et al., 2008; George et al., 2008). The combined evolution of the oxygen to carbon ratio and of the hydrogen to carbon ratio during aerosol aging was recently showed to be consistent with the formation of carboxylic groups (Heald et al., 2010). This is not inconsistent with (a), even though we are not aware of direct evidence for the formation of either FA or AA from the photooxidation of semivolatiles. In contrast, laboratory experiments provide ample evidence for the volatilization of FA and AA (b) following the photolysis of aerosols (Walser et al., 2007; Pan et al., 2009) as well as their heterogeneous oxidation by $\mathrm{O}_{3}$ (Eliason et al., 2003; Park et al., 2006) and OH (Eliason et al., 2004; Molina et al., 2004; Vlasenko et al., 2008). As heterogeneous oxidation operates on relatively long time scales ( $>4$ days George et al., 2008), it could help account for observations during INTEX-B and at Paramaribo. It appears, however, to be too slow to provide a large source of FA and 
AA near emission centers (DeCarlo et al., 2008). These observations suggest that aerosol aging and wall reactions could result in a significant source of FA and AA in chamber experiments that was not accounted for by Paulot et al. (2009).

Comparison between the data and the model suggests global sources of FA and AA may be underestimated by up

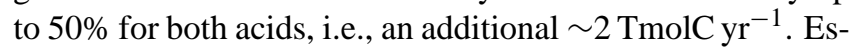
timates for the global flux of carbon from the photooxidation of aerosol range from 4 to $16.5 \mathrm{TmolC} \mathrm{yr}^{-1}$ (Kwan et al., 2006), suggesting FA and AA volatilization would need to account for a very large fraction of this flux (10-50\%). However this estimate does not account for the probably large dynamic exchange of matter between the gas and aerosol phases driven by semivolatile volatilization and photooxidation (Robinson et al., 2007; Kroll et al., 2009; Jimenez et al., 2009).

Proper evaluation of the role of aerosol aging as a source of FA and AA requires detailed modeling of aerosol evolution (e.g., following the framework presented by Jimenez et al., 2009) informed by additional laboratory measurements. This is beyond the scope of this paper. Here, we do not explicitly model secondary organic aerosol but use organic aerosol (OA) to generate a diffuse source of FA and AA associated with aerosol aging (scenario R3). In GEOS-Chem, OA represents both emitted OA (primarily from biomass burning with an important contribution of anthropogenic sources in the Northern midlatitudes) and a small and simplified secondary production from the condensation of low volatility compounds from biogenic and anthropogenic sources (Park et al., 2003). The largest global source of OA is biomass burning globally. We assume that the reaction of $\mathrm{OH}$ with OA produces FA and AA according to:

$$
\frac{d \mathrm{FA}}{d t}=\frac{d \mathrm{AA}}{d t}=\left(\frac{r_{\mathrm{p}}}{D_{\mathrm{g}}}+\frac{4}{v \gamma}\right)^{-1} A \times \mathrm{OH}
$$

where $r_{\mathrm{p}}$ is the particle radius, $\gamma$ the reaction probability (assumed to be 1 here), $D_{\mathrm{g}}$ the gas-phase diffusion coefficient, $v$ the mean molecular velocity of $\mathrm{OH}$ and $A$ the aerosol surface area. This reaction does not represent a physical process (OA is not lost via this reaction) but is meant to provide a diffuse source of FA and AA correlated with OA. Including this process results in an increase in the source of FA and AA by $320 \mathrm{Gmol} \mathrm{yr}^{-1}$, about $\sim 25 \%\left(\sim 0.95 \mathrm{TmolC} \mathrm{yr}^{-1}\right)$.

This large additional FA source greatly improves the agreement with La Réunion. The mean FA concentration increases by almost $60 \%$ in October (Fig. 11a). Similarly, the anomalously high FA measured in December 2006 in Wollongong is much better reproduced in the model with this hypothetical aerosol source (Fig. 11b). We note that it has little effect on the FA total columns for the other years, underlining the exceptional intensity of the 2006 bush fires. For both sites, a similar increase in biomass burning emissions of FA would not result in such a large improvement. This is because the lifetime of organic aerosol is longer than

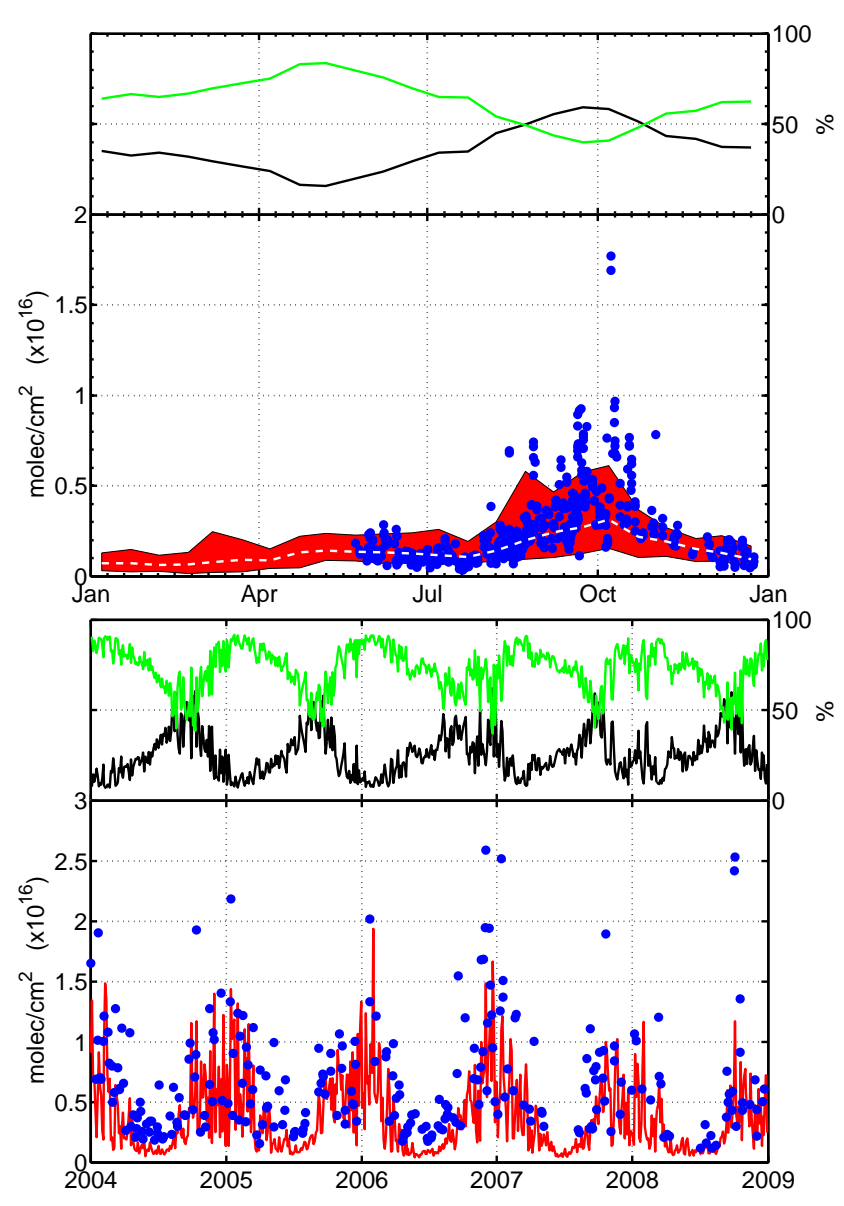

Fig. 11. A diffuse source of FA from aerosol aging (dominated by biomass burning (R3)) allows the model to reproduce the increase in FA during the biomass burning season in La Réunion (a) and Wollongong (b). Color code as Fig. 3.

the lifetime of FA. This is evident in the comparison with the cruise measurements where a very large increase is observed in the tropics, reflecting the enhanced transport of FA biomass burning precursors away from their source regions (Fig. S11). Other locations impacted by biomass burning such as Thule see large increases in FA or AA though this remains insufficient to bridge the gap between model and measurements.

In the GEOS-Chem simulations used in this study, organic aerosol sources are dominated by biomass burning. Because of the lack of a proper representation of secondary organic aerosol (SOA) in our simulation, it is not surprising the discrepancy remains very large in locations where organic aerosols are dominated by SOA from biogenic or anthropogenic sources (e.g., Bremen (Fig. S13), INTEX-B). Future work will focus on assessing the role of semivolatiles as a source of FA and AA. In particular, the interaction between biotic emissions (biogenic and agricultural) and anthropogenic activities need to be properly represented, as it has been shown that this interaction could result in enhanced 
secondary aerosol formation (de Gouw et al., 2005; Weber et al., 2007; Goldstein et al., 2009). If SOA aging is indeed a source of FA and AA, this could help explain the biogenic signature of FA and AA in polluted regions (seasonality and isotopic composition), as well as the similar magnitudes of Wollongong and Bremen FA total columns despite very different isoprene sources.

\subsection{Upper tropospheric budget of FA}

The ACE-FTS comparison revealed a high bias of the model in the upper troposphere. At these altitudes, wet deposition becomes small and FA sink is dominated by the reaction of $\mathrm{OH}$ with FA.

To examine the sensitivity of the FA profile to the temperature dependence of its reaction with $\mathrm{OH}$, we use the temperature dependence derived theoretically by Galano et al. (2002) for the acidic $\left(k_{1}\right)$ and formyl channels $\left(k_{2}\right)$ and scale it to match the experimental rate of $\mathrm{FA}+\mathrm{OH}$ determined at room temperature. The resulting rate constant of $\mathrm{FA}$ with $\mathrm{OH}$ $\left(k_{\mathrm{FA}+\mathrm{OH}}\right)$ is :

$$
\begin{aligned}
k_{\mathrm{FA}+\mathrm{OH}} & =k_{1}+k_{2}=2.94 \times 10^{-14} \times \exp \left(\frac{786}{T}\right) \\
& +9.85 \times 10^{-13} \times \exp \left(-\frac{1036}{T}\right)
\end{aligned}
$$

At $220 \mathrm{~K}$, this predicts the oxidation of FA is 2.3 times faster than at $298 \mathrm{~K}$.

In the R4 simulation, we also include FA formation from organic aerosol (as in R3) as well as the injection of FA in the mid troposphere (as in $\mathrm{R} 2 \mathrm{a}$ ). The change in the reaction rate at cold temperature results in a dramatic decrease of FA in the upper troposphere (Fig. 7), because photooxidation is the dominant sink of FA in this region. This decrease is especially remarkable since mid troposphere FA is increased as a result of the injection of biomass burning in this regions. This result must be interpreted cautiously as the model may underestimate $\mathrm{HO}_{\mathrm{x}}$ in the upper troposphere, especially in the tropics (Wennberg et al., 1998). The fate of FA in the upper troposphere deserves more study since FA could provide a useful proxy to investigate biomass burning injection in the free troposphere.

The discrepancy between model and observation of FA in the upper troposphere is further amplified if the equilibrium between $\mathrm{HOCH}_{2} \mathrm{OO}$ and $\mathrm{HCHO}+\mathrm{HO}_{2}$ is considered (Veyret et al., 1989).

$$
\begin{aligned}
& \mathrm{HCHO}+\mathrm{HO}_{2} \leftrightarrows \mathrm{HOCH} 2 \mathrm{OO} \\
& \mathrm{HOCH}_{2} \mathrm{O}_{2}+\mathrm{HO}_{2} \rightarrow \mathrm{HOCH} 2 \mathrm{OOH} \\
& \mathrm{HOCH}_{2} \mathrm{O}_{2}+\mathrm{HO}_{2} \rightarrow \mathrm{HOCH} 2 \mathrm{O}+\mathrm{OH}+\mathrm{O}_{2} \\
& \mathrm{HOCH}_{2} \mathrm{O}_{2}+\mathrm{HO}_{2} \rightarrow \mathrm{FA}+\mathrm{H}_{2} \mathrm{O}
\end{aligned}
$$

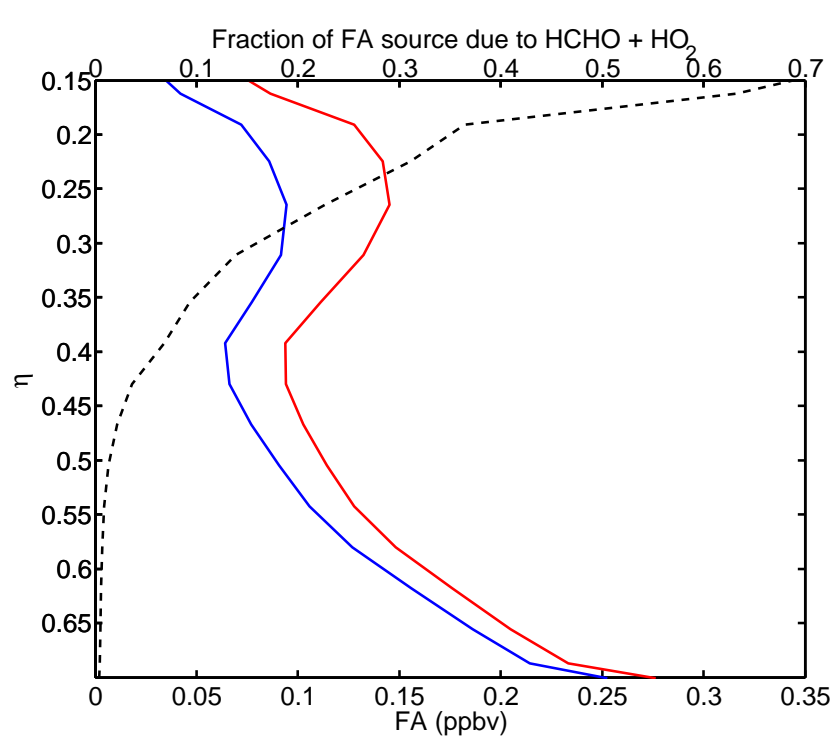

Fig. 12. Including a representation of $\mathrm{HCHO}+\mathrm{HO}_{2}$ chemistry increases FA in the upper troposphere by nearly $50 \%$ (red) compared to the reference run (blue). Such a source (black dashed line) would further amplify the high bias of the model with respect to ACE-FTS observations. Profile of FA at $-14^{\circ} \mathrm{N}, 60^{\circ} \mathrm{W}$ July 2005 .

$$
\begin{aligned}
& \mathrm{HOCH}_{2} \mathrm{O}_{2}+\mathrm{NO} \rightarrow \mathrm{HOCH} 2 \mathrm{O}+\mathrm{NO}_{2} \\
& \mathrm{HOCH}_{2} \mathrm{O}+\mathrm{O}_{2} \rightarrow \mathrm{FA}+\mathrm{HO}_{2} \\
& \mathrm{HOCH}_{2} \mathrm{OOH} \stackrel{S}{\rightarrow} \mathrm{FA} \\
& \mathrm{HOCH}_{2} \mathrm{OOH}+\mathrm{OH} \rightarrow \mathrm{FA}+\mathrm{H}_{2} \mathrm{O}+\mathrm{OH} \\
& \mathrm{HOCH}_{2} \mathrm{OOH}+\mathrm{OH} \rightarrow \mathrm{HOCH}_{2} \mathrm{OO} \\
& \mathrm{HOCH}_{2} \mathrm{OOH}+h v \rightarrow \mathrm{HOCH}_{2} \mathrm{O}+\mathrm{OH}
\end{aligned}
$$

Reaction of $\mathrm{HOCH}_{2} \mathrm{OO}$ with $\mathrm{NO}$ results in FA formation. Jenkin et al. (2007) reported than (R5) and (R6) account for $20 \%$ and $30 \%$ of the reaction of $\mathrm{HOCH}_{2} \mathrm{OO}$ with $\mathrm{HO}_{2}$. The photooxidation of hydroxymethylhydroperoxide $\left(\mathrm{HOCH}_{2} \mathrm{OOH}\right)$ is also expected to form FA with high yield from photolysis, reaction with $\mathrm{OH}$ and heterogeneous decomposition (Neeb et al., 1997). Therefore we assume that the reaction of $\mathrm{HO}_{2}$ with $\mathrm{HOCH}_{2} \mathrm{OO}$ results in FA formation with a yield of 1 . As shown on Fig. 12, $\mathrm{HO}_{2}+\mathrm{HCHO}$ chemistry significantly increases FA in the upper troposphere where the lifetime of $\mathrm{HOCH}_{2} \mathrm{OO}$ is long enough for the reaction of $\mathrm{HOCH}_{2} \mathrm{OO}$ with $\mathrm{NO}$ and $\mathrm{HO}_{2}$ to compete with $\mathrm{HOCH}_{2} \mathrm{OO}$ decomposition. As pointed by Hermans et al. (2005), proper assesment of $\mathrm{HCHO}+\mathrm{HO}_{2}$ importance as a sink of formaldehyde and source of FA requires very precise knowledge of the temperature dependence of (R3). Recent measurements of $\mathrm{HOCH}_{2} \mathrm{OO} \rightarrow \mathrm{HO}_{2}+\mathrm{CH}_{2} \mathrm{O}$ by Pinceloup et al. (2003) are significantly slower than the recommended IUPAC value (Atkinson et al., 2006) used in this simulation. This suggests the source of $\mathrm{FA}$ from $\mathrm{HCHO}+\mathrm{HO}_{2}$ in the free 
troposphere may be even larger than shown on Fig. 12. FA observations in the upper troposphere thus provide a much needed test of the representation of $\mathrm{HCHO}+\mathrm{HO}_{2}$ in models.

\section{Conclusions}

We have derived a detailed bottom-up inventory of FA and AA in the atmosphere. Our updated source of FA is more than twice as large as previous estimates, reflecting the formation of FA from the photooxidation of isoprene and its products by $\mathrm{OH}$. Both carboxylic acids are predicted to originate primarily from the photooxidation of biogenic compounds with biomass burning a significant seasonal source in many environments.

Despite these larger sources, the model remains biased low, especially in the Northern mid latitudes and in air masses affected by biomass burning. This discrepancy cannot be solely resolved by increasing biomass burning emissions of FA and AA.

We propose that a long-lived secondary source of FA and AA of order $\sim 2 \mathrm{TmolC} \mathrm{yr}^{-1}$ has yet to be identified. We hypothesize that the strong correlation of aerosol organic content with FA and AA hints at the possible relationship between aerosol aging and carboxylic acid production. If this relationship is demonstrated, FA and AA could prove very valuable to investigate aerosol aging, composition and sources. A realistic treatment of SOA (especially the missing SOA in polluted regions, including through anthropogenicbiogenic interactions), may help reduce the discrepancy in the mid latitudes where the biomass burning source of organic aerosol is limited.

The comparison between ACE-FTS mid and upper tropospheric measurements also reveals that strong enhancements in FA are consistent with injection of biomass burning emissions outside of the boundary layer (though FA is most likely associated with secondary production). FA may be used as a proxy to track biomass burning injection in the free troposphere, a very uncertain parameter in chemical transport models.

Finally even though the data set presented in this study offers the first long-term overview of the global distribution of FA, many regions of interest (in particular Africa and Asia), remain very poorly sampled. Ongoing efforts to retrieve FA from TES, IASI (Clerbaux et al., 2009; Razavi et al., 2011) or MIPAS-ENVISAT (Grutter et al., 2010) are thus particularly promising.

\section{Supplementary material related to this article is available online at: http://www.atmos-chem-phys.net/11/1989/2011/ acp-11-1989-2011-supplement.pdf.}

Acknowledgement. The authors thank two anonymous referees and T. Stavrakou for their constructive comments. FP is supported by a NASA Earth and Space Science fellowship. GGA is supported by the Wild Fund and the National Center for Earth Observation (NCEO). DBM acknowledges support from NASA under Grant NNX10AG65G. The National Center for Atmospheric Research is supported by the National Science Foundation. The NCAR FTS observation program at Thule (GR) is supported under contract by the National Aeronautics and Space Administration (NASA). This work is also supported by the NSF Office of Polar Programs (OPP). PFD, EJD and JLJ were supported by NASA NNX08AD39G and NOAA NA08OAR4310565. The authors wish to thank the Danish Meteorological Institute for support at the Thule site. JN acknowledges funding by the grant from the Deutsche Forschungsgemeinschaft (DFG) NO 404/14-1. NMD and DWTG acknowledge support from the Australian Department of Innovation, Industry, Science and Research, Internation Science Linkage under Grant CG130014. CV and MDM acknowledge the PRODEX project SECPEA and the project AGACC from the Belgian Science Policy Office (contracts SD/AT/O1A and SD/AT/01B) for supporting the FTIR experiment at La Réunion. Part of this work was performed at the Jet Propulsion Laboratory, California Institute of Technology, under contract with NASA. The ACE mission is supported primarily by the Canadian Space Agency. Some support was also provided by the UK Natural Environment Research Council (NERC), through the National Centre for Earth Observation (NCEO). Measurements of FA and AA during the INTEX-B and Milagro missions were supported by NASA under Grant NNG06GB32B. The authors are grateful to Stephen Arnold and Dominick Spracklen for providing the marine isoprene fluxes, and to Sheryl Akagi and Robert Yokelson for providing updated biomass burning and biofuel emission factors. The numerical simulations for this research were performed on Caltech's Division of Geological and Planetary Sciences Dell cluster.

Edited by: J. P. D. Abbatt

\section{References}

Akagi, S. K., Yokelson, R. J., Wiedinmyer, C., Alvarado, M. J., Reid, J. S., Karl, T., Crounse, J. D., and Wennberg, P. O.: Emission factors for open and domestic biomass burning for use in atmospheric models, Atmos. Chem. Phys. Discuss., 10, 2752327602, doi:10.5194/acpd-10-27523-2010, 2010.

Al-Hosney, H. A., Carlos-Cuellar, S., Baltrusaitis, J., and Grassian, V. H.: Heterogeneous uptake and reactivity of formic acid on calcium carbonate particles: a Knudsen cell reactor, FTIR and SEM study, Phys. Chem. Chem. Phys., 7, 3587-3595, doi:10.1039/b510112c, 2005.

Anderson, C. H., Dibb, J. E., Griffin, R. J., Hagler, G. S., and Bergin, M. H.: Atmospheric water-soluble organic carbon measurements at Summit, Greenland, Atmos. Environ., 42, 56125621, doi:10.1016/j.atmosenv.2008.03.006, 2008.

Andreae, M. O. and Merlet, P.: Emission of trace gases and aerosols from biomass burning, Global Biogeochem. Cy., 15, 955-966, doi:10.1029/2000GB001382, 2001.

Andreae, M. O., Rosenfeld, D., Artaxo, P., Costa, A. A., Frank, G. P., Longo, K. M., and Silva-Dias, M. A. F.: Smok- 
ing Rain Clouds over the Amazon, Science, 303, 1337-1342, doi:10.1126/science.1092779, 2004.

Archibald, A. T., McGillen, M. R., Taatjes, C. A., Percival, C. J., and Shallcross, D. E.: Atmospheric transformation of enols: A potential secondary source of carboxylic acids in the urban troposphere, Geophys. Res. Lett., 34, L21 801, doi:10.1029/2007GL031032, 2007.

Arlander, D. W., Cronn, D. R., Farmer, J. C., Menzia, F. A., and Westberg, H. H.: Gaseous oxygenated hydrocarbons in the remote marine troposphere, J. Geophys. Res., 95, 16391-16403, doi:10.1029/JD095iD10p16391, 1990.

Arnold, S. R., Spracklen, D. V., Williams, J., Yassaa, N., Sciare, J., Bonsang, B., Gros, V., Peeken, I., Lewis, A. C., Alvain, S., and Moulin, C.: Evaluation of the global oceanic isoprene source and its impacts on marine organic carbon aerosol, Atmos. Chem. Phys., 9, 1253-1262, doi:10.5194/acp-9-1253-2009, 2009.

Aschmann, S. M., Arey, J., and Atkinson, R.: OH radical formation from the gas-phase reactions of $\mathrm{O}_{3}$ with methacrolein and methyl vinyl ketone, Atmos. Environ., 30, 2939 - 2943, doi:10.1016/1352-2310(96)00013-1, 1996.

Atkinson, R., Baulch, D. L., Cox, R. A., Crowley, J. N., Hampson, R. F., Hynes, R. G., Jenkin, M. E., Rossi, M. J., Troe, J., and IUPAC Subcommittee: Evaluated kinetic and photochemical data for atmospheric chemistry: Volume II - gas phase reactions of organic species, Atmos. Chem. Phys., 6, 3625-4055, doi:10.5194/acp-6-3625-2006, 2006.

Baboukas, E. D., Kanakidou, M., and Mihalopoulos, N.: Carboxylic acids in gas and particulate phase above the Atlantic Ocean, J. Geophys. Res., 105, 14459-14472, doi:10.1029/1999JD900977, 2000.

Bernath, P. F., McElroy, C. T., Abrams, M. C., Boone, C. D., Butler, M., Camy-Peyret, C., Carleer, M., Clerbaux, C., Coheur, P., Colin, R., DeCola, P., DeMazière, M., Drummond, J. R., Dufour, D., Evans, W. F. J., Fast, H., Fussen, D., Gilbert, K., Jennings, D. E., Llewellyn, E. J., Lowe, R. P., Mahieu, E., McConnell, J. C., McHugh, M., McLeod, S. D., Michaud, R., Midwinter, C., Nassar, R., Nichitiu, F., Nowlan, C., Rinsland, C. P., Rochon, Y. J., Rowlands, N., Semeniuk, K., Simon, P., Skelton, R., Sloan, J. J., Soucy, M., Strong, K., Tremblay, P., Turnbull, D., Walker, K. A., Walkty, I., Wardle, D. A., Wehrle, V., Zander, R., and Zou, J.: Atmospheric Chemistry Experiment (ACE): Mission overview, Geophys. Res. Lett., 32(15), L15S01, doi:10.1029/2005GL022386, 2005.

Bey, I., Jacob, D. J., Yantosca, R. M., Logan, J. A., Field, B. D., Fiore, A. M., Li, Q., Liu, H. Y., Mickley, L. J., Schultz, M. G.: Global modeling of tropospheric chemistry with assimilated meteorology- Model description and evaluation, J. Geophys. Res., 106, 23073-23095, doi:10.1029/2001JD000807, 2001.

Bouwman, A. F. and Hoek, K. W. V. D.: Scenarios of animal waste production and fertilizer use and associated ammonia emission for the developing countries, Atmos. Environ., 31, 4095-4102, doi:10.1016/S1352-2310(97)00288-4, 1997.

Broadgate, W. J., Liss, P. S., and Penkett, S. A.: Seasonal emissions of isoprene and other reactive hydrocarbon gases from the ocean, Geophys. Res. Lett., 24, 2675-2678, doi:10.1029/97GL02736, 1997.

Butkovskaya, N. I., Kukui, A., Pouvesle, N., and Le Bras, G.: Rate constant and mechanism of the reaction of $\mathrm{OH}$ radicals with acetic acid in the temperature range of 229-300 K, J. Phys. Chem.
A, 108, 7021-7026, doi:10.1021/jp048444v, 2004.

Butkovskaya, N. I., Pouvesle, N., Kukui, A., and Bras, G. L.: Mechanism of the $\mathrm{OH}$-initiated oxidation of glycolaldehyde over the temperature range 233-296 K., J. Phys. Chem. A, 110, 1349213499, doi:10.1021/jp064993k, 2006a.

Butkovskaya, N. I., Pouvesle, N., Kukui, A., Mu, Y., and Le Bras, G.: Mechanism of the $\mathrm{OH}$-initiated oxidation of hydroxyacetone over the temperature Range 236-298 K, J. Phys. Chem. A, 110, 6833-6843, doi:10.1021/jp056345r, 2006b.

Capes, G., Johnson, B., McFiggans, G., Williams, P. I., Haywood, J., and Coe, H.: Aging of biomass burning aerosols over West Africa: Aircraft measurements of chemical composition, microphysical properties, and emission ratios, J. Geophys. Res. Atmos., 113, D00C15, doi:10.1029/2008JD009845, 2008.

Capouet, M., Peeters, J., Nozière, B., and Müller, J.-F.: Alphapinene oxidation by $\mathrm{OH}$ : simulations of laboratory experiments, Atmos. Chem. Phys., 4, 2285-2311, doi:10.5194/acp-4-22852004, 2004.

Carlos-Cuellar, S., Li, P., Christensen, A. P., Krueger, B. J., Burrichter, C., and Grassian, V. H.: Heterogeneous uptake kinetics of volatile organic compounds on oxide surfaces using a Knudsen cell reactor: Adsorption of acetic acid, formaldehyde, and methanol on $\alpha-\mathrm{Fe}_{2} \mathrm{O}_{3}, \alpha-\mathrm{Al}_{2} \mathrm{O}_{3}$, and $\mathrm{SiO}_{2}$, J. Phys. Chem. A, 107, 4250-4261, doi:10.1021/jp0267609, 2003.

Carrasco, N., Doussin, J.-F., Picquet-Varrault, B., and Carlier, P.: Tropospheric degradation of 2-hydroxy-2-methylpropanal, a photo-oxidation product of 2-methyl-3-buten-2-ol: Kinetic and mechanistic study of its photolysis and its reaction with $\mathrm{OH}$ radicals, Atmos. Environ., 40, 2011-2019, doi:10.1016/j.atmosenv.2005.11.042, 2006.

Carrasco, N., Doussin, J., O’Connor, M., Wenger, J., PicquetVarrault, B., Durand-Jolibois, R., and Carlier, P.: Simulation chamber studies of the atmospheric oxidation of 2-methyl-3buten-2-ol: Reaction with hydroxyl radicals and ozone under a variety of conditions, J. Atmos. Chem., 56, 33-55, doi:10.1007/s10874-006-9041-y, 2007.

Chameides, W. L.: The photochemistry of a remote marine stratiform cloud, J. Geophys. Res., 89, 4739-4755, doi:10.1029/JD089iD03p04739, 1984.

Chebbi, A. and Carlier, P.: Carboxylic acids in the troposphere, occurrence, sources, and sinks: A review, Atmos. Environ., 30, 4233-4249, doi:10.1016/1352-2310(96)00102-1, 1996.

Christian, T. J., Kleiss, B., Yokelson, R. J., Holzinger, R., Crutzen, P. J., Hao, W. M., Saharjo, B. H., and Ward, D. E.: Comprehensive laboratory measurements of biomass-burning emissions: 1 . Emissions from Indonesian, African, and other fuels, J. Geophys. Res., 108, 4719, doi:10.1029/2003JD003704, 2003.

Clerbaux, C., Boynard, A., Clarisse, L., George, M., Hadji-Lazaro, J., Herbin, H., Hurtmans, D., Pommier, M., Razavi, A., Turquety, S., Wespes, C., and Coheur, P.-F.: Monitoring of atmospheric composition using the thermal infrared IASI/MetOp sounder, Atmos. Chem. Phys., 9, 6041-6054, doi:10.5194/acp-9-6041-2009, 2009.

Crounse, J. D., McKinney, K. A., Kwan, A. J., and Wennberg, P. O.: Measurement of gas-phase hydroperoxides by chemical ionization mass spectrometry., Anal. Chem., 78, 6726-6732, doi:10.1021/ac0604235, 2006.

Crowley, J. N., Ammann, M., Cox, R. A., Hynes, R. G., Jenkin, M. E., Mellouki, A., Rossi, M. J., Troe, J., and Wallington, T. J.: 
Evaluated kinetic and photochemical data for atmospheric chemistry: Volume V - heterogeneous reactions on solid substrates, Atmos. Chem. Phys., 10, 9059-9223, doi:10.5194/acp-10-90592010, 2010.

da Silva, G.: Carboxylic Acid Catalyzed Keto-Enol Tautomerizations in the Gas Phase, Angew. Chem., 49, 7523-7525, doi:10.1002/anie.201003530, 2010.

Davidson, E.: Pulses of nitric oxide and nitrous oxide flux following wetting of dry soil: An assessment of probable sources and importance relative to annual fluxes, Ecol. Bull., 149-155, 1992.

de Gouw, J. A. and Warneke, C.: Measurements of volatile organic compounds in the earth's atmosphere using proton-transferreaction mass spectrometry, Mass Spectrom. Rev., 26, 223-257, doi:10.1002/mas.20119, 2007.

de Gouw, J. A., Middlebrook, A. M., Warneke, C., Goldan, P. D., Kuster, W. C., Roberts, J. M., Fehsenfeld, F. C., Worsnop, D. R., Canagaratna, M. R., Pszenny, A. A. P., Keene, W. C., Marchewka, M., Bertman, S. B., and Bates, T. S.: Budget of organic carbon in a polluted atmosphere: Results from the New England Air Quality Study in 2002, J. Geophys. Res. Atmos., 110, 16305, doi:10.1029/2004JD005623, 2005.

de Gouw, J. A., Warneke, C., Stohl, A., Wollny, A. G., Brock, C. A., Cooper, O. R., Holloway, J. S., Trainer, M., Fehsenfeld, F. C., Atlas, E. L., Donnelly, S. G., Stroud, V., and Lueb, A.: Volatile organic compounds composition of merged and aged forest fire plumes from Alaska and western Canada, J. Geophys. Res. Atmos., 111, 10303, doi:10.1029/2005JD006175, 2006.

DeCarlo, P. F., Dunlea, E. J., Kimmel, J. R., Aiken, A. C., Sueper, D., Crounse, J., Wennberg, P. O., Emmons, L., Shinozuka, Y., Clarke, A., Zhou, J., Tomlinson, J., Collins, D. R., Knapp, D., Weinheimer, A. J., Montzka, D. D., Campos, T., and Jimenez, J. L.: Fast airborne aerosol size and chemistry measurements above Mexico City and Central Mexico during the MILAGRO campaign, Atmos. Chem. Phys., 8, 4027-4048, doi:10.5194/acp8-4027-2008, 2008.

Dibb, J. E. and Arsenault, M.: Shouldn't snowpacks be sources of monocarboxylic acids?, Atmos. Environ., 36, 2513-2522, doi:10.1016/S1352-2310(02)00131-0, 2002.

Dillon, T. J. and Crowley, J. N.: Direct detection of $\mathrm{OH}$ formation in the reactions of $\mathrm{HO}_{2}$ with $\mathrm{CH}_{3} \mathrm{C}(\mathrm{O}) \mathrm{O}_{2}$ and other substituted peroxy radicals, Atmos. Chem. Phys., 8, 4877-4889, http://www. atmos-chem-phys.net/8/4877/2008/, 2008.

Duncan, B. N., Logan, J. A., Bey, I., Megretskaia, I. A., Yantosca, R. M., Novelli, P. C., Jones, N. B., and Rinsland, C. P.: Global budget of CO, 1988-1997: Source estimates and validation with a global model, J. Geophys. Res. Atmos., 112, 22301, doi:10.1029/2007JD008459, 2007.

Dunlea, E. J., DeCarlo, P. F., Aiken, A. C., Kimmel, J. R., Peltier, R. E., Weber, R. J., Tomlinson, J., Collins, D. R., Shinozuka, Y., McNaughton, C. S., Howell, S. G., Clarke, A. D., Emmons, L. K., Apel, E. C., Pfister, G. G., van Donkelaar, A., Martin, R. V., Millet, D. B., Heald, C. L., and Jimenez, J. L.: Evolution of Asian aerosols during transpacific transport in INTEX-B, Atmos. Chem. Phys., 9, 7257-7287, doi:10.5194/acp-9-7257-2009, 2009.

Eichler, A., Brütsch, S., Olivier, S., Papina, T., and Schwikowski, M.: A 750 year ice core record of past biogenic emissions from Siberian boreal forests, Geophys. Res. Lett., 36, 18813, doi:10.1029/2009GL038807, 2009.
Eliason, T. L., Aloisio, S., Donaldson, D. J., Cziczo, D. J., and Vaida, V.: Processing of unsaturated organic acid films and aerosols by ozone, Atmos. Environ., 37, 2207-2219, doi:10.1016/S1352-2310(03)00149-3, 2003.

Eliason, T. L., Gilman, J. B., and Vaida, V.: Oxidation of organic films relevant to atmospheric aerosols, Atmos. Environ., 38, 1367-1378, doi:10.1016/j.atmosenv.2003.11.025, 2004.

Enders, G., Dlugi, R., Steinbrecher, R., Clement, B., Daiber, R., Eijk, J., Gäb, S., Haziza, M., Helas, G., Herrmann, U., Kessel, M., Kesselmeier, J., Kotzias, D., Kourtidis, K., Kurth, H.-H., McMillen, R., Roider, G., Schürmann, W., Teichmann, U., and Torres, L.: Biosphere/Atmosphere interactions: Integrated research in a European coniferous forest ecosystem, Atmospheric Environment. Part A. General Topics, 26, 171-189, doi:10.1016/0960-1686(92)90269-Q, 1992.

Fairlie, T. D., Jacob, D. J., and Park, R. J.: The impact of transpacific transport of mineral dust in the United States, Atmos. Environ., 41, 1251-1266, doi:10.1016/j.atmosenv.2006.09.048, 2007.

Falkovich, A. H., Schkolnik, G., Ganor, E., and Rudich, Y.: Adsorption of organic compounds pertinent to urban environments onto mineral dust particles, J. Geophys. Res. Atmos., 109, D02208, doi:10.1029/2003JD003919, 2004.

Fehsenfeld, F. C., Ancellet, G., Bates, T. S., Goldstein, A. H., Hardesty, R. M., Honrath, R., Law, K. S., Lewis, A. C., Leaitch, R., McKeen, S., Meagher, J., Parrish, D. D., Pszenny, A. A. P., Russell, P. B., Schlager, H., Seinfeld, J., Talbot, R., and Zbinden, R.: International Consortium for Atmospheric Research on Transport and Transformation (ICARTT): North America to EuropeOverview of the 2004 summer field study, J. Geophys. Res. Atmos., 111, D23S01, doi:10.1029/2006JD007829, 2006.

Fu, T., Jacob, D. J., Wittrock, F., Burrows, J. P., Vrekoussis, M., and Henze, D. K.: Global budgets of atmospheric glyoxal and methylglyoxal, and implications for formation of secondary organic aerosols, J. Geophys. Res. Atmos., 113, 15303 , doi:10.1029/2007JD009505, 2008.

Fuhrer, K. and Legrand, M.: Continental biogenic species in the Greenland Ice Core Project ice core: Tracing back the biomass history of the North American continent, J. Geophys. Res., 102, 26735-26746, doi:10.1029/97JC01299, 1997.

Galano, A., Alvarez-Idaboy, J., Ruiz-Santoyo, M., and VivierBunge, A.: Rate coefficient and mechanism of the gas phase $\mathrm{OH}$ hydrogen abstraction reaction from formic acid: A quantum mechanical approach, J. Phys. Chem. A, 106, 9520-9528, doi:10.1021/jp020297i, 2002.

Galloway, J. N., Likens, G. E., Keene, W. C., and Miller, J. M.: The composition of precipitation in remote areas of the world, J. Geophys. Res., 87, 8771-8786, doi:10.1029/JC087iC11p08771, 1982.

Gao, S., Hegg, D., Hobbs, P., Kirchstetter, T., Magi, B., and Sadilek, M.: Water-soluble organic components in aerosols associated with savanna fires in southern Africa: Identification, evolution, and distribution, J. Geophys. Res., 108, 8491, doi:10.1029/2002JD002324, 2003.

George, I. J., Slowik, J., and Abbatt, J. P. D.: Chemical aging of ambient organic aerosol from heterogeneous reaction with hydroxyl radicals, Geophys. Res. Lett., 35, 13811, doi:10.1029/2008GL033884, 2008.

Giglio, L., Randerson, J. T., van der Werf, G. R., Kasibhatla, P. S., Collatz, G. J., Morton, D. C., and DeFries, R. S.: Assess- 
ing variability and long-term trends in burned area by merging multiple satellite fire products, Biogeosciences, 7, 1171-1186, doi:10.5194/bg-7-1171-2010, 2010.

Glasius, M., Wessel, S., Christensen, C., Jacobsen, J., Jørgensen, H., Klitgaard, K., Petersen, L., Rasmussen, J., Stroyer Hansen, T., Lohse, C., Boaretto, E., and Heinemeier, J.: Sources to formic acid studied by carbon isotopic analysis and air mass characterization, Atmos. Environ., 34, 2471-2479, doi:10.1016/S13522310(99)00416-1, 2000.

Glasius, M., Boel, C., Bruun, N., Easa, L. M., Hornung, P., Klausen, H. S., Klitgaard, K. C., Lindeskov, C., Møller, C. K., Nissen, H., Petersen, A. P. F., Kleefeld, S., Boaretto, E., Hansen, T. S., Heinemeier, J., and Lohse, C.: Relative contribution of biogenic and anthropogenic sources to formic and acetic acids in the atmospheric boundary layer, J. Geophys. Res., 106, 7415-7426, doi:10.1029/2000JD900676, 2001.

Goldstein, A. H., Koven, C. D., Heald, C. L., and Fung, I. Y.: Biogenic carbon and anthropogenic pollutants combine to form a cooling haze over the southeastern United States, P. Natl. Acad. Sci. USA, 106, 8835-8840, doi:10.1073/pnas.0904128106, 2009.

Gonzàlez Abad, G., Bernath, P. F., Boone, C. D., McLeod, S. D., Manney, G. L., and Toon, G. C.: Global distribution of upper tropospheric formic acid from the ACE-FTS, Atmos. Chem. Phys., 9, 8039-8047, doi:10.5194/acp-9-8039-2009, 2009.

Goode, J. G., Yokelson, R. J., Ward, D. E., Susott, R. A., Babbitt, R. E., Davies, M. A., and Hao, W. M.: Measurements of excess $\mathrm{O}_{3}, \mathrm{CO}_{2}, \mathrm{CH}_{4}, \mathrm{C}_{2} \mathrm{H}_{4}, \mathrm{C}_{2} \mathrm{H}_{2}, \mathrm{HCN}, \mathrm{NO}, \mathrm{NH}_{3}$, $\mathrm{HCOOH}, \mathrm{CH}_{3} \mathrm{COOH}, \mathrm{HCHO}$, and $\mathrm{CH}_{3} \mathrm{OH}$ in 1997 Alaskan biomass burning plumes by airborne Fourier transform infrared spectroscopy (AFTIR), J. Geophys. Res., 105, 22147-22166, doi:10.1029/2000JD900287, 2000.

Graedel, T. E. and Eisner, T.: Atmospheric formic acid from formicine ants: a preliminary assessment, Tellus B, 40, 335-339, doi:10.1111/j.1600-0889.1988.tb00107.x, 1988.

Grosjean, D., Williams, E. L., and Grosjean, E.: Atmospheric chemistry of isoprene and of its carbonyl products, Environ. Sci. Technol., 27, 830-840, doi:10.1021/es00042a004, 1993.

Grutter, M., Glatthor, N., Stiller, G. P., Fischer, H., Grabowski, U., Höpfner, M., Kellmann, S., Linden, A., and von Clarmann, T.: Global distribution and variability of formic acid as observed by MIPAS-ENVISAT, J. Geophys. Res. Atmos., 115, 10303, doi:10.1029/2009JD012980, 2010.

Guenther, A., Geron, C., Pierce, T., Lamb, B., Harley, P., and R., F.: Natural emissions of non-methane volatile organic compounds, carbon monoxide, and oxides of nitrogen from North America, Atmos. Environ., 34, 2205-2230, doi:10.1016/S13522310(99)00465-3, 2000.

Guenther, A., Karl, T., Harley, P., Wiedinmyer, C., Palmer, P. I., and Geron, C.: Estimates of global terrestrial isoprene emissions using MEGAN (Model of Emissions of Gases and Aerosols from Nature), Atmos. Chem. Phys., 6, 3181-3210, doi:10.5194/acpd6-107-2006, 2006.

Harley, P., Fridd-Stroud, V., Greenberg, J., Guenther, A., and Vasconcellos, P.: Emission of 2-methyl-3-buten-2-ol by pines- A potentially large natural source of reactive carbon to the atmosphere, J. Geophys. Res., 103(25), 25479-25486, doi:10.1029/98JD00820, 1998.

Hasson, A. S., Tyndall, G. S., and Orlando, J. J.: A product yield study of the reaction of $\mathrm{HO}_{2}$ radicals with ethyl peroxy $\left(\mathrm{C}_{2} \mathrm{H}_{5} \mathrm{O}_{2}\right)$, acetyl peroxy $\left(\mathrm{CH}_{3} \mathrm{C}(\mathrm{O}) \mathrm{O}_{2}\right)$, and acetonyl peroxy $\left(\mathrm{CH}_{3} \mathrm{C}(\mathrm{O}) \mathrm{CH}_{2} \mathrm{O}_{2}\right)$ radicals, J. Phys. Chem. A, 108, 5979-5989, doi:10.1021/jp048873t, 2004.

Hatakeyama, S., Washida, N., and Akimoto, H.: Rate constants and mechanisms for the reaction of hydroxyl (OD) radicals with acetylene, propyne, and 2-butyne in air at $297 \pm 2 \mathrm{~K}$, J. Phys. Chem., 90, 173-178, doi:10.1021/j100273a039, 1986.

Hatch, C. D., Gough, R. V., and Tolbert, M. A.: Heterogeneous uptake of the $\mathrm{C}_{1}$ to $\mathrm{C}_{4}$ organic acids on a swelling clay mineral, Atmos. Chem. Phys., 7, 4445-4458, http://www.atmos-chem-phys. net/7/4445/2007/, 2007.

Heald, C. L., Kroll, J. H., Jimenez, J. L., Docherty, K. S., DeCarlo, P. F., Aiken, A. C., Chen, Q., Martin, S. T., Farmer, D. K., and Artaxo, P.: A simplified description of the evolution of organic aerosol composition in the atmosphere, Geophys. Res. Lett., 37, 8803, doi:10.1029/2010GL042737, 2010.

Hermans, I., Müller, J. F., Nguyen, T. L., Jacobs, P., and Peeters, J.: Kinetics of-Hydroxy-alkylperoxyl Radicals in Oxidation Processes. $\mathrm{HO}_{2}$ Initiated Oxidation of Ketones/Aldehydes near the Tropopause, J. Phys. Chem. A, 109, 4303-4311, 2005.

Herndon, S. C., Zahniser, M. S., Nelson, D. D., Shorter, J., McManus, J. B., Jiménez, R., Warneke, C., and de Gouw, J. A.: Airborne measurements of $\mathrm{HCHO}$ and $\mathrm{HCOOH}$ during the New England Air Quality Study 2004 using a pulsed quantum cascade laser spectrometer, J. Geophys. Res. Atmos., 112, D10S03, doi:10.1029/2006JD007600, 2007.

Huang, Y. W., Dransfield, T. J., Miller, J. D., Rojas, R. D., Castillo, X. G., and Anderson, J. G.: Experimental Study of the Kinetics of the Reaction of Acetic Acid with Hydroxyl Radicals from 255 to 355 K, J. Phys. Chem. A, 113, 423-430, doi:10.1021/jp808627w, 2009.

Ito, A., Sillman, S., and Penner, J. E.: Effects of additional nonmethane volatile organic compounds, organic nitrates, and direct emissions of oxygenated organic species on global tropospheric chemistry, J. Geophys. Res., 112, D06309, doi:10.1029/2005JD006556, 2007.

Jacob, D. J.: Chemistry of $\mathrm{OH}$ in remote clouds and its role in the production of formic acid and peroxymonosulfate, J. Geophys. Res., 91, 9807-9826, doi:10.1029/JD091iD09p09807, 1986.

Jacob, D. J. and Wofsy, S. C.: Photochemistry of biogenic emissions over the Amazon forest, J. Geophys. Res., 93, 1477-1486, doi:10.1029/JD093iD02p01477, 1988.

Jenkin, M. E., Hurley, M. D., and Wallington, T. J.: Investigation of the radical product channel of the $\mathrm{CH}_{3} \mathrm{C}(\mathrm{O}) \mathrm{O}_{2}+\mathrm{HO}_{2}$ reaction in the gas phase, Phys. Chem. Chem. Phys., 9, 3149-3162, 2007.

Jimenez, J. L., Canagaratna, M. R., Donahue, N. M., Prevot, A. S. H., Zhang, Q., Kroll, J. H., DeCarlo, P. F., Allan, J. D., Coe, H., Ng, N. L., Aiken, A. C., Docherty, K. S., Ulbrich, I. M., Grieshop, A. P., Robinson, A. L., Duplissy, J., Smith, J. D., Wilson, K. R., Lanz, V. A., Hueglin, C., Sun, Y. L., Tian, J., Laaksonen, A., Raatikainen, T., Rautiainen, J., Vaattovaara, P., Ehn, M., Kulmala, M., Tomlinson, J. M., Collins, D. R., Cubison, M. J., E., Dunlea, J., Huffman, J. A., Onasch, T. B., Alfarra, M. R., Williams, P. I., Bower, K., Kondo, Y., Schneider, J., Drewnick, F., Borrmann, S., Weimer, S., Demerjian, K., Salcedo, D., Cottrell, L., Griffin, R., Takami, A., Miyoshi, T., Hatakeyama, S., Shimono, A., Sun, J. Y., Zhang, Y. M., Dzepina, K., Kimmel, J. R., Sueper, D., Jayne, J. T., Herndon, S. C., Trim- 
born, A. M., Williams, L. R., Wood, E. C., Middlebrook, A. M., Kolb, C. E., Baltensperger, U., and Worsnop, D. R.: Evolution of Organic Aerosols in the Atmosphere, Science, 326, 1525-1529, doi:10.1126/science.1180353, 2009.

Karl, M., Guenther, A., Köble, R., Leip, A., and Seufert, G.: A new European plant-specific emission inventory of biogenic volatile organic compounds for use in atmospheric transport models, Biogeosciences, 6, 1059-1087, doi:10.5194/bg-6-1059-2009, 2009.

Kawamura, K., Ng, L., and Kaplan, I.: Determination of organic acids $(\mathrm{C} 1-\mathrm{C} 10)$ in the atmosphere, motor exhausts, and engine oils, Environ. Sci. Technol., 19, 1082-1086, doi:10.1021/es00141a010, 1985.

Keene, W. C. and Galloway, J. N.: The biogeochemical cycling of formic and acetic acids through the troposphere An overview of current understanding, Tellus B, 40, 322-334, doi:10.1111/j.1600-0889.1988.tb00106.x, 1988.

Kesselmeier, J.: Exchange of short-chain oxygenated volatile organic compounds (VOCs) between plants and the atmosphere: A compilation of field and laboratory studies, J. Atmos. Chem., 39, 219-233, doi:10.1023/A:1010632302076, 2001.

Kesselmeier, J. and Staudt, M.: Biogenic Volatile Organic Compounds (VOC): An Overview on Emission, Physiology and Ecology, J. Atmos. Chem., 33, 23-88, doi:10.1023/A:1006127516791, 1999.

Kesselmeier, J., Bode, K., Gerlach, C., and Jork, E.: Exchange of atmospheric formic and acetic acids with trees and crop plants under controlled chamber and purified air conditions, Atmos. Environ., 32, 1765-1775, doi:10.1016/S1352-2310(97)00465-2, 1998.

Khare, P., Kumar, N., Kumari, K. M., and Srivastava, S. S.: Atmospheric formic and acetic acids: An overview, Rev. Geophys., 37, 227-248, doi:10.1029/1998RG900005, 1999.

Kroll, J. H., Smith, J. D., Che, D. L., Kessler, S. H., Worsnop, D. R., and Wilson, K. R.: Measurement of fragmentation and functionalization pathways in the heterogeneous oxidation of oxidized organic aerosol, Phys. Chem. Chem. Phys., 11, 8005o, doi:10.1039/b905289e, 2009.

Kurylo, M. and Solomon, S.: Network for the detection of stratospheric change: a status and implementation report, NASA and NOAA Special Report, 1990.

Kwan, A. J., Crounse, J. D., Clarke, A. D., Shinozuka, Y., Anderson, B. E., Crawford, J. H., Avery, M. A., McNaughton, C. S., Brune, W. H., Singh, H. B., and Wennberg, P. O.: On the flux of oxygenated volatile organic compounds from organic aerosol oxidation, Geophys. Res. Lett., 33, L15815, doi:10.1029/2006GL026144, 2006.

Larsen, B. R., Di Bella, D., Glasius, M., Winterhalter, R., Jensen, N. R., and Hjorth, J.: Gas-phase OH oxidation of monoterpenes: Gaseous and particulate products, J. Atmos. Chem., 38, 231-276, doi:10.1023/A:1006487530903, 2001.

Lathière, J., Hauglustaine, D. A., Friend, A. D., De NobletDucoudré, N., Viovy, N., and Folberth, G. A.: Impact of climate variability and land use changes on global biogenic volatile organic compound emissions, Atmos. Chem. Phys., 6, 2129-2146, doi:10.5194/acp-6-2129-2006, 2006.

Lee, A., Goldstein, A. H., Keywood, M. D., Gao, S., Varutbangkul, V., Bahreini, R., Ng, N. L., Flagan, R. C., and Seinfeld, J. H.: Gas-phase products and secondary aerosol yields from the ozonolysis of ten different terpenes, J. Geophys. Res.,
111, D07302, doi:10.1029/2005JD006437, 2006.

Lee, M., Heikes, B. G., and O'Sullivan, D. W.: Hydrogen peroxide and organic hydroperoxide in the troposphere: a review, Atmos. Environ., 34, 3475-3494, doi:10.1016/S1352-2310(99)00432-X, 2000.

Lee, S., Murphy, D. M., Thomson, D. S., and Middlebrook, A. M.: Chemical components of single particles measured with Particle Analysis by Laser Mass Spectrometry (PALMS) during the Atlanta SuperSite Project: Focus on organic/sulfate, lead, soot, and mineral particles, J. Geophys. Res., 107, 4003, doi:10.1029/2000JD000011, 2002.

Legrand, M. and De Angelis, M.: Light carboxylic acids in Greenland ice: A record of past forest fires and vegetation emissions from the boreal zone, J. Geophys. Res., 101, 4129-4146, doi:10.1029/95JD03296, 1996.

Lelieveld, J. and Crutzen, P.: The role of clouds in tropospheric photochemistry, J. Atmos. Chem., 12, 229-267, doi:10.1007/BF00048075, 1991.

Liu, H., Jacob, D. J., Bey, I., and Yantosca, R. M.: Constraints from ${ }^{210} \mathrm{~Pb}$ and ${ }^{7} \mathrm{Be}$ on wet deposition and transport in a global three-dimensional chemical tracer model driven by assimilated meteorological fields, J. Geophys. Res., 106, 12109-12128, doi:10.1029/2000JD900839, 2001.

Marécal, V., Pirre, M., Rivière, E. D., Pouvesle, N., Crowley, J. N., Freitas, S. R., and Longo, K. M.: Modelling the reversible uptake of chemical species in the gas phase by ice particles formed in a convective cloud, Atmos. Chem. Phys., 10, 4977-5000, doi:10.5194/acp-10-4977-2010, 2010.

Mari, C., Bechtold, P., and Jacob, D.: Transport and scavenging of soluble gases in a deep convective cloud, J. Geophys. Res., 105, 22255-22268, doi:10.1029/2000JD900211, 2000.

Millet, D. B., Guenther, A., Siegel, D. A., Nelson, N. B., Singh, H. B., de Gouw, J. A., Warneke, C., Williams, J., Eerdekens, G., Sinha, V., Karl, T., Flocke, F., Apel, E., Riemer, D. D., Palmer, P. I., and Barkley, M.: Global atmospheric budget of acetaldehyde: 3-D model analysis and constraints from in-situ and satellite observations, Atmos. Chem. Phys., 10, 3405-3425, http://www.atmos-chem-phys.net/10/3405/2010/, 2010.

Molina, M. J., Ivanov, A. V., Trakhtenberg, S., and Molina, L. T.: Atmospheric evolution of organic aerosol, Geophys. Res. Lett., 31, 22 104, doi:10.1029/2004GL020910, 2004.

Neeb, P., Sauer, F., Horie, O., and Moortgat, G. K.: Formation of hydroxymethyl hydroperoxide and formic acid in alkene ozonolysis in the presence of water vapour, Atmos. Environ., 31, 14171423, doi:10.1016/S1352-2310(96)00322-6, 1997.

Ngwabie, N. M., Schade, G. W., Custer, T. G., Linke, S., and Hinz, T.: Abundances and flux estimates of volatile organic compounds from a dairy cowshed in Germany, J. Environ. Qual., 37, 565573, doi:10.2134/jeq2006.0417, 2008.

Orlando, J. J., Nozière, B., Tyndall, G. S., Orzechowska, G. E., Paulson, S. E., and Rudich, Y.: Product studies of the OH- and ozone-initiated oxidation of some monoterpenes, J. Geophys. Res., 105, 11 561-11 572, doi:10.1029/2000JD900005, 2000.

Otter, L. B., Guenther, A., and Greenberg, J.: Seasonal and spatial variations in biogenic hydrocarbon emissions from southern African savannas and woodlands, Atmos. Environ., 36, 42654275, doi:10.1016/S1352-2310(02)00333-3, 2002.

Pan, X., Underwood, J. S., Xing, J.-H., Mang, S. A., and Nizkorodov, S. A.: Photodegradation of secondary organic aerosol gen- 
erated from limonene oxidation by ozone studied with chemical ionization mass spectrometry, Atmos. Chem. Phys., 9, 38513865, doi:10.5194/acp-9-3851-2009, 2009.

Park, R. J., Jacob, D. J., Chin, M., and Martin, R. V.: Sources of carbonaceous aerosols over the United States and implications for natural visibility, J. Geophys. Res. Atmos., 108, 4355, doi:10.1029/2002JD003190, 2003.

Park, J., Gomez, A. L., Walser, M. L., Lin, A., and Nizkorodov, S. A.: Ozonolysis and photolysis of alkene-terminated selfassembled monolayers on quartz nanoparticles: implications for photochemical aging of organic aerosol particles, Phys. Chem. Chem. Phys., 8, 2506, doi:10.1039/b602704k, 2006.

Parrish, D. D., Allen, D. T., Bates, T. S., Estes, M., Fehsenfeld, F. C., Feingold, G., Ferrare, R., Hardesty, R. M., Meagher, J. F., Nielsen-Gammon, J. W., Pierce, R. B., Ryerson, T. B., Seinfeld, J. H., and Williams, E. J.: Overview of the Second Texas Air Quality Study (TexAQS II) and the Gulf of Mexico Atmospheric Composition and Climate Study (GoMACCS), J. Geophys. Res. Atmos., 114, D00F13, doi:10.1029/2009JD011842, 2009.

Paton-Walsh, C., Jones, N. B., Wilson, S. R., Haverd, V., Meier, A., Griffith, D. W. T., and Rinsland, C. P.: Measurements of trace gas emissions from Australian forest fires and correlations with coincident measurements of aerosol optical depth, J. Geophys. Res. Atmos., 110, 24305, doi:10.1029/2005JD006202, 2005.

Paulot, F., Crounse, J. D., Kjaergaard, H. G., Kroll, J. H., Seinfeld, J. H., and Wennberg, P. O.: Isoprene photooxidation: new insights into the production of acids and organic nitrates, Atmos. Chem. Phys., 9, 1479-1501, http://www.atmos-chem-phys.net/ 9/1479/2009/, 2009.

Peeters, J., Vereecken, L., and Fantechi, G.: The detailed mechanism of the $\mathrm{OH}$-initiated atmospheric oxidation of $\alpha$-pinene: a theoretical study, Phys. Chem. Chem. Phys., 3, 5489-5504, doi:10.1039/b106555f, 2001.

Peeters, J., Nguyen, T., and Vereecken, L.: $\mathrm{HO}_{\mathrm{x}}$ radical regeneration in the oxidation of isoprene, Phys. Chem. Chem. Phys., 11, 5935-5939, doi:10.1039/b908511d, 2009.

Peters, W., Krol, M. C., Fortuin, J. P. F., Kelder, H. M., Thompson, A. M., Becker, C. R., Lelieveld, J., and Crutzen, P. J.: Tropospheric ozone over a tropical Atlantic station in the Northern Hemisphere: Paramaribo, Surinam $\left(6^{\circ} \mathrm{N}, 55^{\circ} \mathrm{W}\right)$, Tellus B, 56, 21-34, doi:10.1111/j.1600-0889.2004.00083.x, 2004.

Petersen, A. K., Warneke, T., Lawrence, M. G., Notholt, J., and Schrems, O.: First ground-based FTIR observations of the seasonal variation of carbon monoxide in the tropics, Geophys. Res. Lett., 35, 3813, doi:10.1029/2007GL031393, 2008.

Pinceloup, S., Laverdet, G., Maguin, F., Doussin, J. F., Carlier, P., and Bras, G. L.: Laboratory investigation of the photooxidation of formaldehyde combining FTIR analysis of stable species and $\mathrm{HO} 2$ detection by the chemical amplifier technique, J. Photochem. Photobiol., A, 157, 275-281, doi:10.1016/S10106030(03)00066-2, 2003.

Poisson, N., Kanakidou, M., and Crutzen, P. J.: Impact of Non-Methane Hydrocarbons on Tropospheric Chemistry and the Oxidizing Power of the Global Troposphere: 3Dimensional Modelling Results, J. Atmos. Chem., 36, 157-230, doi:10.1023/A:1006300616544, 2000.

Prince, A., Kleiber, P., Grassian, V., and Young, M.: Reactive uptake of acetic acid on calcite and nitric acid reacted calcite aerosol in an environmental reaction chamber, Phys. Chem.
Chem. Phys., 10, 142-152, doi:10.1039/b712915g, 2008.

Randerson, J. T., van der Werf, G. R., Giglio, L., Collatz, G. J., and Kasibhatla, P. S.: Global Fire Emissions Database, Version 2 (GFEDv2), Tech. rep., Oak Ridge National Laboratory Distributed Active Archive Center, Oak Ridge, TN, USA, doi:10.3334/ORNLDAAC/834, 2006.

Razavi, A., Karagulian, F., Clarisse, L., Hurtmans, D., Coheur, P. F., Clerbaux, C., Müller, J. F., and Stavrakou, T.: Global distributions of methanol and formic acid retrieved for the first time from the IASI/MetOp thermal infrared sounder, Atmos. Chem. Phys., 11, 857-872, doi:10.5194/acp-11-857-2011, 2011.

Rinsland, C. P., Boone, C. D., Bernath, P. F., Mahieu, E., Zander, R. , Dufour, G., Clerbaux, C., Turquety, S., Chiou, L., Mc-Connell, J. C., Neary, L., and Kaminski, J. W.: Atmospheric Chemistry Experiment austral spring 2004 and 2005 Southern Hemisphere tropical-mid-latitude upper tropospheric measurements, Geophys. Res. Lett, 33, L23804, doi:10.1029/2006GL027128, 2006.

Rinsland, C. P., Dufour, G., Boone, C. D., Bernath, P. F., Chiou, L., Coheur, P.-F., Turquety, S., and Clerbaux, C.: Satellite boreal measurements over Alaska and Canada during June-July 2004: Simultaneous measurements of upper tropospheric CO, $\mathrm{C}_{2} \mathrm{H}_{6}, \mathrm{HCN}, \mathrm{CH}_{3} \mathrm{Cl}, \mathrm{CH}_{4}, \mathrm{C}_{2} \mathrm{H}_{2}, \mathrm{CH}_{3} \mathrm{OH}, \mathrm{HCOOH}, \mathrm{OCS}$, and $\mathrm{SF}_{6}$ mixing ratios, Global Biogeochem. Cy., 21, B3008, doi:10.1029/2006GB002795, 2007.

Robinson, A. L., Donahue, N. M., Shrivastava, M. K., Weitkamp, E. A., Sage, A. M., Grieshop, A. P., Lane, T. E., Pierce, J. R., and Pandis, S. N.: Rethinking Organic Aerosols: Semivolatile Emissions and Photochemical Aging, Science, 315, 1259, doi:10.1126/science.1133061, 2007.

Rothman, L. S., Gordon, I. E., Barbe, A., Benner, D. C., Bernath, P. F., Birk, M., Boudon, V., Brown, L. R., Campargue, A., Champion, J.-P., Chance, K., Coudert, L. H., Dana, V., Devi, V. M., Fally, S., Flaud, J.-M., Gamache, R. R., Goldman, A., Jacquemart, D., Kleiner, I., Lacome, N., Lafferty, W. J., Mandin, J.-Y., Massie, S. T., Mikhailenko, S. N., Miller, C. E., Moazzen-Ahmadi, N., Naumenko, O. V., Nikitin, A. V., Orphal, J., Perevalov, V. I., Perrin, A., Predoi-Cross, A., Rinsland, C. P., Rotger, M., Simeckov, M., Smith, M. A. H., Sung, K., Tashkun, S. A., Tennyson, J., Toth, R. A., Vandaele, A. C., and Auwera, J. V.: The HITRAN 2008 molecular spectroscopic database, J. Quant. Spectrosc. Ra., 110, 533-572, doi:10.1016/j.jqsrt.2009.02.013, 2009.

Russell, L. M., Maria, S. F., and Myneni, S. C. B.: Mapping organic coatings on atmospheric particles, Geophys. Res. Lett., 29, 1779, doi:10.1029/2002GL014874, 2002.

Sander, R.: Compilation of Henry's Law Constants for Inorganic and Organic Species of Potential Importance in Environmental Chemistry (Version 3), Tech. rep., 1999.

Sanhueza, E. and Andreae, M. O.: Emission of formic and acetic acids from tropical savanna soils, Geophys. Res. Lett., 18, 17071710, doi:10.1029/91GL01565, 1991.

Sanhueza, E., Figueroa, L., and Santana, M.: Atmospheric formic and acetic acids in Venezuela, Atmos. Environ., 30, 1861-1873, doi:10.1016/1352-2310(95)00383-5, joint 8th CAGCP and 2nd IGAC Conference on Global Atmospheric Chemistry, 1996.

Shaw, S., Mitloehner, F., Jackson, W., DePeters, E., Fadel, J., Robinson, P., Holzinger, R., and Goldstein, A.: Volatile organic compound emissions from dairy cows and their waste as mea- 
sured by proton-transfer-reaction mass spectrometry, Environ. Sci. Technol, 41, 1310-1316, doi:10.1021/es061475e, 2007.

Singh, H. B., Brune, W. H., Crawford, J. H., Flocke, F., and Jacob, D. J.: Chemistry and transport of pollution over the Gulf of Mexico and the Pacific: spring 2006 INTEX-B campaign overview and first results, Atmos. Chem. Phys., 9, 2301-2318, doi:10.5194/acp-9-2301-2009, 2009.

Sinreich, R., Coburn, S., Dix, B., and Volkamer, R.: Ship-based detection of glyoxal over the remote tropical Pacific Ocean, Atmos. Chem. Phys., 10, 11359-11371, doi:10.5194/acp-1011359-2010, 2010.

Sposito, G.: The Chemistry of Soils, Oxford University. Press, 1989.

Sun, W. and Saeys, M.: first principles Study of the Reaction of Formic and Acetic Acids with Hydroxyl Radicals, J. Phys. Chem. A, 112, 6918-6928, doi:10.1021/jp802017q, 2008.

Taatjes, C. A., Hansen, N., McIlroy, A., Miller, J. A., Senosiain, J. P., Klippenstein, S. J., Qi, F., Sheng, L., Zhang, Y., Cool, T. A., Wang, J., Westmoreland, P. R., Law, M. E., Kasper, T., and Kohse-Höinghaus, K.: Enols Are Common Intermediates in Hydrocarbon Oxidation, Science, 308, 1887-1889, doi:10.1126/science.1112532, 2005.

Talbot, R. W., Beecher, K. M., and Harriss, R. C.: Atmospheric geochemistry of formic and acetic acids at a midlatitude temperate site, J. Geophys. Res., 93, 1638-1652, doi:10.1029/JD093iD02p01638, 1988.

Turquety, S., Logan, J. A., Jacob, D. J., Hudman, R. C., Leung, F. Y., Heald, C. L., Yantosca, R. M., Wu, S., Emmons, L. K., Edwards, D. P., and Sachse, G. W.: Inventory of boreal fire emissions for North America in 2004: Importance of peat burning and pyroconvective injection, J. Geophys. Res. Atmos., 112, D12S03, doi:10.1029/2006JD007281, 2007.

Usher, C. R., Michel, A. E., and Grassian, V. H.: Reactions on mineral dust, Chem. Rev, 103, 4883-4940, doi:10.1021/cr020657y, 2003.

Val Martin, M., Logan, J. A., Kahn, R. A., Leung, F.-Y., Nelson, D. L., and Diner, D. J.: Smoke injection heights from fires in North America: analysis of 5 years of satellite observations, Atmos. Chem. Phys., 10, 1491-1510, doi:10.5194/acp-10-14912010 , 2010.

Vander Auwera, J., Didriche, K., Perrin, A., and Keller, F.: Absolute line intensities for formic acid and dissociation constant of the dimer, J. Chem. Phys., 126, 124311-124320, doi:10.1063/1.2712439, 2007.

Velazco, V., Notholt, J., Warneke, T., Lawrence, M., Bremer, H., Drummond, J., Schulz, A., Krieg, J., and Schrems, O.: Latitude and altitude variability of carbon monoxide in the Atlantic detected from ship-borne Fourier transform spectrometry, model, and satellite data, J. Geophys. Res. Atmos., 110, 9306, doi:10.1029/2004JD005351, 2005.

Veyret, B., Lesclaux, R., Rayez, M. T., Rayez, J. C., Cox, R. A., and Moortgat, G. K.: Kinetics and mechanism of the photo-oxidation of formaldehyde. 1. Flash photolysis study, J. Phys. Chem., 93, 2368-2374, 1989.

Vigouroux, C., Hendrick, F., Stavrakou, T., Dils, B., De Smedt, I., Hermans, C., Merlaud, A., Scolas, F., Senten, C., Vanhaelewyn, G., Fally, S., Carleer, M., Metzger, J.-M., Müller,
J.-F., Van Roozendael, M., and De Mazière, M.: Groundbased FTIR and MAX-DOAS observations of formaldehyde at Réunion Island and comparisons with satellite and model data, Atmos. Chem. Phys., 9, 9523-9544, doi:10.5194/acp-9-95232009, 2009.

Vlasenko, A., George, I. J., and Abbatt, J. P. D.: Formation of Volatile Organic Compounds in the Heterogeneous Oxidation of Condensed-Phase Organic Films by Gas-Phase OH, J. Phys. Chem. A, 112, 1552-1560, doi:10.1021/jp0772979, 2008.

von Kuhlmann, R., Lawrence, M., Crutzen, P., and Rasch, P.: A model for studies of tropospheric ozone and nonmethane hydrocarbons: Model evaluation of ozone-related species, J. Geophys. Res.-Atmos., 108, 4729, doi:10.1029/2002JD003348, 2003a.

von Kuhlmann, R., Lawrence, M. G., Crutzen, P. J., and Rasch, P. J.: A model for studies of tropospheric ozone and nonmethane hydrocarbons: Model description and ozone results, J. Geophys. Res. Atmos., 108, 4294, doi:10.1029/2002JD002893, 2003 b.

Walser, M. L., Park, J., Gomez, A. L., Russell, A. R., and Nizkorodov, S. A.: Photochemical Aging of Secondary Organic Aerosol Particles Generated from the Oxidation of d-Limonene, J. Phys. Chem. A, 111, 1907-1913, doi:10.1021/jp0662931, 2007.

Wang, Y. and Jacob, D.: Anthropogenic forcing on tropospheric ozone and $\mathrm{OH}$ since preindustrial times, J. Geophys. Res., 103, 31123-31136, doi:10.1029/1998JD100004, 1998.

Wang, Y., Jacob, D. J., and Logan, J. A.: Global simulation of tropospheric $\mathrm{O}_{3}-\mathrm{NO}_{\mathrm{x}}$-hydrocarbon chemistry 1 . Model formulation, J. Geophys. Res., 103, 10713-10726, doi:10.1029/98JD00158, 1998.

Warneke, C., Bahreini, R., Brioude, J., Brock, C. A., de Gouw, J. A., Fahey, D. W., Froyd, K. D., Holloway, J. S., Middlebrook, A., Miller, L., Montzka, S., Murphy, D. M., Peischl, J., Ryerson, T. B., Schwarz, J. P., Spackman, J. R., and Veres, P.: Biomass burning in Siberia and Kazakhstan as an important source for haze over the Alaskan Arctic in April 2008, Geophys. Res. Lett., 36, 2813, doi:10.1029/2008GL036194, 2009.

Weber, R. J., Sullivan, A. P., Peltier, R. E., Russell, A., Yan, B., Zheng, M., de Gouw, J., Warneke, C., Brock, C., Holloway, J. S., Atlas, E. L., and Edgerton, E.: A study of secondary organic aerosol formation in the anthropogenic-influenced southeastern United States, J. Geophys. Res. Atmos., 112, 13302, doi:10.1029/2007JD008408, 2007.

Wennberg, P. O., Hanisco, T. F., Jaeglé;, L., Jacob, D. J., Hintsa, E. J., Lanzendorf, E. J., Anderson, J. G., Gao, R.-S., Keim, E. R., Donnelly, S. G., Negro, L. A., Fahey, D. W., McKeen, S. A., Salawitch, R. J., Webster, C. R., May, R. D., Herman, R. L., Proffitt, M. H., Margitan, J. J., Atlas, E. L., Schauffler, S. M., Flocke, F., McElroy, C. T., and Bui, T. P.: Hydrogen Radicals, Nitrogen Radicals, and the Production of $\mathrm{O}_{3}$ in the Upper Troposphere, Science, 279, 49-53, doi:10.1126/science.279.5347.49, 1998.

Wesely, M. . L.: Parameterization of surface resistances to gaseous dry deposition in regional-scale numerical models, Atmos. Environ., 23, 1293-1304, doi:10.1016/j.atmosenv.2007.10.058, 1989.

Wiedinmyer, C., Guenther, A., Harley, P., Hewitt, N., Geron, C., Artaxo, P., Steinbrecher, R., and Rasmussen, R.: Global Organic Emissions from Vegetation (in Emissions of Atmospheric Trace Compounds), 18 of Advances in Global Change Research, Springer, 2004.

Yevich, R. and Logan, J. A.: An assessment of biofuel use and 
burning of agricultural waste in the developing world., Global Biogeochem. Cy., 17, 1095, doi:10.1029/2002GB001952, 2003.

Yienger, J. J. and Levy, H.: Empirical model of global soilbiogenic NOx emissions, J. Geophys. Res., 100, 11447-11464, doi:10.1029/95JD00370, 1995.

Yokelson, R. J., Bertschi, I. T., Christian, T. J., Hobbs, P. V., Ward, D. E., and Hao, W. M.: Trace gas measurements in nascent, aged, and cloud-processed smoke from African savanna fires by airborne Fourier transform infrared spectroscopy (AFTIR), J. Geophys. Res., 108, 8478, doi:10.1029/2002JD002322, 2003.

Yokelson, R. J., Crounse, J. D., DeCarlo, P. F., Karl, T., Urbanski, S., Atlas, E., Campos, T., Shinozuka, Y., Kapustin, V., Clarke, A. D., Weinheimer, A., Knapp, D. J., Montzka, D. D., Holloway, J., Weibring, P., Flocke, F., Zheng, W., Toohey, D., Wennberg, P. O., Wiedinmyer, C., Mauldin, L., Fried, A., Richter, D., Walega, J., Jimenez, J. L., Adachi, K., Buseck, P. R., Hall, S. R., and Shetter, R.: Emissions from biomass burning in the Yucatan, Atmospheric Chemistry and Physics, 9, 5785-5812, doi:10.5194/acp-9-5785-2009, 2009.
York, D., Evensen, N. M., Martínez, M. L., and Delgado, J. D. B.: Unified equations for the slope, intercept, and standard errors of the best straight line, Am. J. Phys., 72, 367-375, doi:10.1119/1.1632486, 2004.

Zander, R., Duchatelet, P., Mahieu, E., Demoulin, P., Roland, G., Servais, C., Auwera, J. V., Perrin, A., Rinsland, C. P., and Crutzen, P. J.: Formic acid above the Jungfraujoch during 1985-2007: observed variability, seasonality, but no long-term background evolution, Atmos. Chem. Phys., 10, 10047-10065, doi:10.5194/acp-10-10047-2010, 2010.

Zender, C. S., Bian, H., and Newman, D.: Mineral Dust Entrainment and Deposition (DEAD) model: Description and 1990s dust climatology, J. Geophys. Res. Atmos., 108, 4416, doi:10.1029/2002JD002775, 2003. 